\title{
Immunological memory to SARS-CoV-2 assessed for up to 8 months after infection
}

\author{
Jennifer M. Dan ${ }^{1,3 *}$, Jose Mateus ${ }^{1 *}$, Yu Kato ${ }^{*}$, Kathryn M. Hastie ${ }^{1}$, Esther Dawen Yu', Caterina E. Faliti', Alba \\ Grifoni $^{1}$, Sydney I. Ramirez ${ }^{1,3}$, Sonya Haupt ${ }^{1}$, April Frazier', Catherine Nakao', Vamseedhar Rayaprolu', Stephen \\ A. Rawlings ${ }^{3}$, Bjoern Peters ${ }^{1,2}$, Florian Krammer ${ }^{4}$, Viviana Simon ${ }^{4,5,6}$, Erica Ollmann Saphire ${ }^{1,3}$, Davey M. \\ Smith $^{3}$, Daniela Weiskopf ${ }^{1} \uparrow$, Alessandro Sette ${ }^{1,3}+$, Shane Crotty ${ }^{1,3} \uparrow$
}

\begin{abstract}
${ }^{1}$ Center for Infectious Disease and Vaccine Research, La Jolla Institute for Immunology (LJI), La Jolla, CA 92037, USA. 2Department of Medicine, University of California, San Diego (UCSD), La Jolla, CA 92037, USA. ${ }^{3}$ Department of Medicine, Division of Infectious Diseases and Global Public Health, University of California, San Diego (UCSD), La Jolla, CA 92037, USA. ${ }^{4}$ Department of Microbiology, Icahn School of Medicine at Mount Sinai, New York, NY 10029, USA. ${ }^{5}$ Division of Infectious Diseases, Department of Medicine, Icahn School of Medicine at Mount Sinai, New York, NY 10029, USA. ${ }^{6}$ The Global Health and Emerging Pathogens Institute, Icahn School of Medicine at Mount Sinai, New York, NY 10029, USA.
\end{abstract}

*These authors contributed equally to this work.

†Corresponding author. Email: shane@lji.org (S.C.); alex@lji.org (A.S.); daniela@lji.org (D.W.)

Understanding immune memory to SARS-CoV-2 is critical for improving diagnostics and vaccines, and for assessing the likely future course of the COVID-19 pandemic. We analyzed multiple compartments of circulating immune memory to SARS-CoV-2 in 254 samples from 188 COVID-19 cases, including 43 samples at $\geq 6$ months post-infection. IgG to the Spike protein was relatively stable over $6+$ months. Spike-specific memory $B$ cells were more abundant at 6 months than at 1 month post symptom onset. SARS-CoV-2specific $\mathrm{CD}^{+} \mathrm{T}$ cells and $\mathrm{CD} 8^{+} \mathrm{T}$ cells declined with a half-life of 3-5 months. By studying antibody, memory $\mathrm{B}$ cell, CD4 ${ }^{+} \mathrm{T}$ cell, and CD8 ${ }^{+} \mathrm{T}$ cell memory to SARS-CoV-2 in an integrated manner, we observed that each component of SARS-CoV-2 immune memory exhibited distinct kinetics.

Coronavirus disease 2019 (COVID-19), caused by the novel severe acute respiratory syndrome coronavirus 2 (SARS-CoV-2), is a serious disease that has resulted in widespread global morbidity and mortality. Humans make SARS-CoV-2-specific antibodies, $\mathrm{CD} 4^{+} \mathrm{T}$ cells, and $\mathrm{CD} 8^{+} \mathrm{T}$ cells in response to SARS-CoV-2 infection (1-4). Studies of acute and convalescent COVID-19 patients have observed that $\mathrm{T}$ cell responses are associated with reduced disease (5-7), suggesting that SARS-CoV-2-specific $\mathrm{CD} 4^{+} \mathrm{T}$ cell and $\mathrm{CD} 8^{+} \mathrm{T}$ cell responses may be important for control and resolution of primary SARS-CoV-2 infection. Ineffective innate immunity has been strongly associated with a lack of control of primary SARSCoV-2 infection and a high risk of fatal COVID-19 (8-12), accompanied by innate cell immunopathology (13-18). Neutralizing antibodies have generally not correlated with lessened COVID-19 disease severity $(5,19,20)$, which was also observed for Middle Eastern respiratory syndrome (MERS), caused by MERS-CoV (21). Instead, neutralizing antibodies are associated with protective immunity against secondary infection with SARS-CoV-2 or SARS-CoV in non-human primates (3, 22-25). Passive transfer of neutralizing antibodies in advance of infection (mimicking pre-existing conditions upon secondary exposure) effectively limits upper respiratory tract (URT) infection, lower respiratory tract (lung) infection, and symptomatic disease in animal models (26-28). Passive transfer of neutralizing antibodies provided after initiation of infection in humans have had more limited effects on COVID-19 (29, 30 ), consistent with a substantial role for $\mathrm{T}$ cells in control and clearance of an ongoing SARS-CoV-2 infection. Thus, studying antibody, memory $\mathrm{B}$ cell, $\mathrm{CD} 4^{+} \mathrm{T}$ cell, and $\mathrm{CD} 8^{+} \mathrm{T}$ cell memory to SARS-CoV-2 in an integrated manner is likely important for understanding the durability of protective immunity against COVID-19 generated by primary SARS-CoV-2 infection $(1,19,31)$.

While sterilizing immunity against viruses can only be accomplished by high-titer neutralizing antibodies, successful protection against clinical disease or death can be accomplished by several other immune memory scenarios. Possible mechanisms of immunological protection can vary based on the relative kinetics of the immune memory responses and infection. For example, clinical hepatitis after hepatitis B virus (HBV) infection is prevented by vaccine-elicited immune memory even in the absence of circulating antibodies, because of the relatively slow course of $\mathrm{HBV}$ disease $(32,33)$. The relatively slow course of severe COVID-19 in humans (median 19 days post-symptom onset (PSO) for fatal cases (34)) suggests that protective immunity against symptomatic or severe secondary COVID-19 may involve memory compartments such as circulating memory T cells and memory B cells (which can take several days to reactivate and generate recall $\mathrm{T}$ cell responses and/or anamnestic antibody responses) (19, 21,31 ). 
Immune memory, from either primary infection or immunization, is the source of protective immunity from a subsequent infection (35-37). Thus, COVID-19 vaccine development relies on immunological memory $(1,3)$. Despite intensive study, the kinetics, duration, and evolution of immune memory in humans to infection or immunization are not in general predictable based on the initial effector phase, and immune responses at short time points after resolution of infection are not very predictive of long-term memory (3840). Thus, assessing responses over an interval of six months or more is usually required to ascertain the durability of immune memory.

A thorough understanding of immune memory to SARSCoV-2 requires evaluation of its various components, including $\mathrm{B}$ cells, $\mathrm{CD} 8^{+} \mathrm{T}$ cells, and $\mathrm{CD} 4^{+} \mathrm{T}$ cells, as these different cell types may have immune memory kinetics relatively independent of each other. Understanding the complexities of immune memory to SARS-CoV-2 is key to gain insights into the likelihood of durability of protective immunity against re-infection with SARS-CoV-2 and secondary COVID-19 disease. In the current study, we assessed immune memory of all three branches of adaptive immunity $\left(\mathrm{CD} 4^{+} \mathrm{T}\right.$ cell, $\mathrm{CD} 8^{+} \mathrm{T}$ cell, and humoral immunity) in a predominantly cross-sectional study of 188 recovered COVID-19 cases, extending up to eight months post-infection. The findings have implications for immunity against secondary COVID-19, and thus the potential future course of the pandemic $(41,42)$.

\section{COVID-19 cohort}

188 individuals with COVID-19 were recruited for this study. Subjects (80 male, 108 female) represented a range of asymptomatic, mild, moderate, and severe COVID-19 cases (Table 1), and were recruited from multiple sites throughout the United States. The majority of subjects were from California or New York. Most subjects had a "mild" case of COVID-19, not requiring hospitalization. $93 \%$ of subjects were never hospitalized for COVID-19; 7\% of subjects were hospitalized, some of whom required intensive care unit (ICU) care (Table 1). This case severity distribution was consistent with the general distribution of symptomatic disease severity among COVID-19 cases in the USA. The study primarily consisted of symptomatic disease cases ( $97 \%$, Table 1$)$, due to the nature of the study recruitment design. Subject ages ranged from 19 to 81 years old (Table 1). Most subjects provided a blood sample at a single time point, between 6 days post-symptom onset (PSO) and 240 days PSO (Table 1), with 43 samples at $\geq 6$ months PSO (178 days or longer). Additionally, 51 subjects in the study provided longitudinal blood samples over a duration of several months (2-4 time points; Table 1), allowing for longitudinal assessment of immune memory in a subset of the cohort.

\section{SARS-CoV-2 circulating antibodies over time}

The vast majority of SARS-CoV-2 infected individuals seroconvert, at least for a duration of months $(1,2,4,43-45)$. Seroconversion rates range from $91-99 \%$ in large studies (44, 45). Durability assessments of circulating antibody titers in Fig. 1 were based on data $\geq 20$ days PSO, with the plot of the best fitting curve fit model shown in blue (see Methods). SARS-CoV-2 Spike immunoglobulin G (IgG) endpoint ELISA titers in plasma were measured for all subjects of this cohort (Fig. 1, A and B). Spike receptor binding domain (RBD) IgG was also measured (Fig. 1, C and D), as RBD is the target of most neutralizing antibodies against SARS-CoV-2 $(4,27,46$, 47). SARS-CoV-2 pseudovirus (PSV) neutralizing antibody titers were measured in all subjects (Fig. 1, E and F). Nucleocapsid (N) IgG endpoint ELISA titers were also measured for all subjects (Fig. 1, G and H), as Nucleocapsid is a common antigen in commercial SARS-CoV-2 serological test kits.

SARS-CoV-2 Spike IgG titers were relatively stable from 20-240 days PSO, when assessing all COVID-19 subjects by cross-sectional analysis (half-life $t_{1 / 2}=140$ days, Fig. 1A). Spike IgG titers were heterogeneous among subjects (range 5 to 73,$071 ; 575$ median), as has been widely observed $(45,47)$. This gave a wide confidence interval for the Spike IgG $t_{1 / 2}$ (95\% CI: 89 to 325 days). While the antibody responses may have more complex underlying decay kinetics, the best fit curve was a continuous decay, likely related to heterogeneity between individuals. SARS-CoV-2 Nucleocapsid IgG kinetics were similar to Spike IgG over 8 months ( $t_{1 / 2} 68$ days, $95 \%$ CI: 50-106 days, Fig. 1G). As a complementary approach, using paired samples from the subset of subjects who donated at two or more time points, the calculated Spike IgG titer average $t_{1 / 2}$ was 103 days, (95\% CI: 66-235 days, Fig. 1B) and the Nucleocapsid IgG titer average $t_{1 / 2}$ was 68 days, (95\% CI: 55 90 days, Fig. $1 \mathrm{H})$. The percentage of subjects seropositive for Spike IgG at 1 month PSO (20-50 days) was 98\% (54/55). The percentage of subjects seropositive for Spike IgG at 6 to 8 months PSO ( $\geq 178$ days) was $90 \%$ (36/40).

Cross-sectional analysis of SARS-CoV-2 RBD IgG titers from 20-240 days PSO gave an estimated $t_{1 / 2}$ of 83 days (95\% CI: 62-126 days, Fig. 1C). As a complementary approach, we again used paired samples, which gave an average $t_{1 / 2}$ of 69 days (95\% CI: 58-87 days, Fig. 1D). The percentage of subjects seropositive for RBD IgG at 6 to 8 months PSO was $88 \%$ $(35 / 40)$. Thus, RBD IgG titer maintenance largely matched that of Spike IgG. SARS-CoV-2 PSV neutralization titers in the full cohort largely matched the results of SARS-CoV-2 RBD IgG ELISA binding titers (Fig. 1, $\mathrm{E}$ and $\mathrm{F}$ ). A one-phase decay model was the best fit $\left(\mathrm{P}=0.015, \mathrm{~F}\right.$ test. Initial decay $t_{1 / 2} 27$ days, followed by an extended plateau phase. Fig. 1E), while a continuous decay fit gave an estimated $t_{1 / 2}$ of 114 days (Fig. $1 \mathrm{E}$, black line). Paired timepoints analysis of the PSV neutralization titers gave an estimated $t_{1 / 2}$ of 90 days, (95\% CI: 70 - 
125 days, Fig. 1F). The percentage of subjects seropositive for SARS-CoV-2 neutralizing antibodies (titer $\geq 20$ ) at 6 to 8 months PSO was 90\% (36/40). Notably, even low levels of circulating neutralizing antibody titers $(\geq 1: 20)$ were associated with a substantial degree of protection against COVID-19 in non-human primates $(24,48)$. Thus, modest levels of circulating SARS-CoV-2 neutralizing antibodies are of biological interest in humans.

SARS-CoV-2 Spike IgA (Fig. 1, I and J) and RBD IgA (Fig. $1, \mathrm{~K}$ and $\mathrm{L}$ ) titers were also assessed. Paired timepoints analysis of Spike IgA titers yielded an estimated $t_{1 / 2}$ of 210 days (95\% CI 126-703 days, Fig. 1J). Cross-sectional analysis of Spike IgA fit a short one-phase decay model with an extended plateau phase (initial $t_{1 / 2}$ of 14 days, Fig. 1I). Circulating RBD IgA had an estimated initial $t_{1 / 2}$ of 27 days, decaying by $\sim 90$ days in most COVID-19 cases to levels indistinguishable from uninfected controls (Fig. 1K), consistent with observations 3 months PSO $(44,49)$. By paired sample analysis, long-lasting RBD IgA was made in some subjects, but often near the limit of sensitivity (LOS) (Fig. 1L).

\section{SARS-CoV-2 memory B cells}

To identify SARS-CoV-2-specific memory B cells, fluorescently labeled multimerized probes were used to detect B cells specific to Spike, RBD, and Nucleocapsid (Fig. 2A and fig. S1). Antigen-binding memory $\mathrm{B}$ cells (defined as $\mathrm{IgD}^{-}$ and/or $\mathrm{CD} 27^{+}$) were further distinguished according to surface Ig isotypes: IgM, IgG or IgA (Fig. 2B and fig. S1).

Cross-sectional analysis of COVID-19 subjects revealed that frequencies of SARS-CoV-2 Spike-specific memory B cells increased over the first $\sim 120$ days PSO and then plateaued (pseudo-first order model for best fit curve, $\mathrm{R}=0.38$. Better fit than second order polynomial model by Akaike's Information Criterion. Fig. 2C and fig. S2A). Spike-specific memory B cell frequencies increased from the first time-point (36-163 days) to the second time-point (111-240 days) in paired samples from 24 of 36 longitudinally tracked donors (Fig. 2D). Spike-specific memory B cells in SARS-CoV-2unexposed subjects were rare (median 0.0078\%. Fig. 2, A and C).

RBD-specific memory B cells displayed similar kinetics to Spike-specific memory B cells. RBD-specific memory B cells were undetectable in SARS-CoV-2 unexposed subjects (Fig. $2 \mathrm{E}$ and fig. S2C), as expected. RBD-specific memory B cells appeared as early as 16 days PSO, and the frequency steadily increased in the following 4-5 months (Fig. 2E and fig. S2, B and C). 29 of 36 longitudinally tracked individuals had higher frequencies of RBD-specific memory B cells at the later time point (Fig. 2F), again showing an increase in SARS-CoV-2 specific memory B cells several months post-infection. $10-30 \%$ of Spike-specific memory B cells from SARS-CoV-2 convalescent donors were specific for the RBD domain (Fig. 2A and fig. S2B).

SARS-CoV-2 Nucleocapsid-specific memory B cells were also detected after SARS-CoV-2 infection (Fig. 2A). Similar to Spike- and RBD-specific memory B cells, Nucleocapsid-specific memory B cell frequency steadily increased during the first 4-5 months PSO (Fig. 2, G and H, and fig. S2D). Antibody affinity maturation could potentially explain the increased frequencies of SARS-CoV-2-specific memory B cells detected by the antigen probes. However, geometric mean fluorescent intensity (MFI) of probe binding was stable over time (fig. S2, I and J), not supporting an affinity maturation explanation for the increased memory B cell frequencies.

Representation of Ig isotypes among the SARS-CoV-2 Spike-specific memory B cell population shifted with time (Fig. 2, I to O). During the earliest phase of memory (20-60 days PSO), $\mathrm{IgM}^{+}$and $\mathrm{IgG}^{+}$isotypes were similarly represented (Fig. 2O), but IgM $^{+}$memory B cells then declined (Fig. 2, M to $\mathrm{O})$, and $\mathrm{IgG}^{+}$Spike-specific memory B cells then dominated by 6 months PSO (Fig. 2O). IgA ${ }^{+}$Spike-specific memory B cells were detected as a small fraction of the total Spike-specific memory B cells ( $5 \%$, Fig. 2O). IgG $^{+}$Spike-specific memory B cell frequency increased while $\operatorname{IgA}^{+}$was low and stable over the 8 months period (Fig. 2, I to L). Similar patterns of increasing IgG $^{+}$memory, short-lived IgM $^{+}$memory, and stable $\mathrm{IgA}^{+}$memory were observed for RBD- and Nucleocapsid-specific memory $\mathrm{B}$ cells over the 8 months period (Fig. 2, $\mathrm{O}$ to $\mathrm{Q}$, and fig. $\mathrm{S} 2, \mathrm{E}$ to $\mathrm{H}$ ).

There is limited knowledge of memory B cell kinetics following primary acute viral infection in humans. A recently published SARS-CoV-2 study found RBD-specific memory $\mathrm{B}$ cells out to $\sim 90$ days PSO, with increasing frequencies (and a low frequency of $\mathrm{IgA}^{+}$cells) (50), consistent with observations reported here. For other acute infectious diseases, we are not currently aware of other cross-sectional or longitudinal analyses of antigen-specific memory B cells by flow cytometry covering a $6+$ month window after infection, except for four individuals with Ebola (51) and two individuals studied after yellow fever virus immunization (52) (we exclude influenza vaccines for comparison here, because people have numerous exposures and complex immune history to influenza). In the yellow fever study, short-lived IgM $^{+}$memory and longer-lasting isotype-switched memory B cells were observed in the two individuals. Overall, based on the observations here, development of B cell memory to SARS-CoV-2 was robust, and is likely long-lasting.

\section{SARS-CoV-2 memory $\mathrm{CDB}^{+} \mathrm{T}$ cells}

SARS-CoV-2 memory $\mathrm{CD}^{+} \mathrm{T}$ cells were measured in 169 COVID-19 subjects using a series of 23 peptide pools covering the entirety of the SARS-CoV-2 ORFeome $(2,5)$. The most commonly recognized ORFs were Spike, Membrane (M), Nucleocapsid, and ORF3a $\left(\mathrm{CD} 69^{+} \mathrm{CD} 137^{+}\right.$, Fig. 3A and fig. S3, A 
and B), consistent with our previous study (2). The percentage of subjects with detectable circulating SARS-CoV-2 memory $\mathrm{CD}^{+} \mathrm{T}$ cells at 1 month PSO (20-50 days) was $70 \%$ (40/57, Fig. 3B). The proportion of subjects positive for SARSCoV-2 memory $\mathrm{CD}^{+} \mathrm{T}$ cells at $\geq 6$ months PSO was $50 \%$ (18/36). This could potentially underestimate $\mathrm{CD}^{+} \mathrm{T}$ cell memory, as 15-mers can be suboptimal for detection of some antigen-specific CD8 ${ }^{+} \mathrm{T}$ cells (53); however, pools of predicted SARS-CoV-2 class I epitope of optimal size also detected virus-specific $\mathrm{CD}^{+} \mathrm{T}$ cells in $\sim 70 \%$ of individuals $1-2$ months PSO, indicating consistency between the two experimental approaches (2).

SARS-CoV-2 memory CD8 ${ }^{+} \mathrm{T}$ cells declined with an apparent $t_{1 / 2}$ of 125 days in the full cohort (Fig. 3B) and $t_{1 / 2} 190$ days among 29 paired samples (Fig. 3C). Spike-specific memory $\mathrm{CD}^{+} \mathrm{T}$ cells exhibited similar kinetics to the overall SARSCoV-2-specific memory $\mathrm{CD}^{+} \mathrm{T}$ cells $\left(t_{1 / 2} 225\right.$ days for the full cohort and 185 days among paired samples, Fig. 3, D and E, respectively). Phenotypic markers indicated that the majority of SARS-CoV-2-specific memory CD8 ${ }^{+} \mathrm{T}$ cells were terminally differentiated effector memory cells ( $\left.\mathrm{T}_{\mathrm{EMRA}}\right)(54)$, with small populations of central memory $\left(\mathrm{T}_{\mathrm{CM}}\right)$ and effector memory $\left(\mathrm{T}_{\mathrm{EM}}\right.$ ) (Fig. 3, F and G). In the context of influenza, $\mathrm{CD} 8^{+} \mathrm{T}_{\mathrm{EMRA}}$ cells were associated with protection against severe disease in humans (55). The memory $\mathrm{CD}^{+} \mathrm{T}$ cell half-lives observed here were comparable to the 123 days $t_{1 / 2}$ observed for memory $\mathrm{CD}^{+} \mathrm{T}$ cells after yellow fever immunization (56). Thus, the kinetics of circulating SARS-CoV-2-specific $\mathrm{CD}^{+} \mathrm{T}$ cell were consistent with what has been reported for another virus that causes acute infections in humans.

\section{SARS-CoV-2 memory $\mathbf{C D 4}^{+} \mathbf{T}$ cells}

SARS-CoV-2 memory CD4 ${ }^{+} \mathrm{T}$ cells were identified in 169 subjects using the same series of 23 peptide pools covering the SARS-CoV-2 ORFeome $(2,5)$. The most commonly recognized ORFs were Spike, M, Nucleocapsid, ORF3a, and nsp3 (CD137 ${ }^{+}$ $\mathrm{OX}_{40}{ }^{+}$, Fig. $4 \mathrm{~A}$ and fig. S4, A and B), consistent with our previous study (2). Circulating SARS-CoV-2 memory CD4 ${ }^{+} \mathrm{T}$ cell responses were quite robust (Fig. 4B); 42\% (24/57) of COVID19 cases at 1 month PSO had > 1.0\% SARS-CoV-2-specific $\mathrm{CD}^{+}{ }^{+} \mathrm{T}$ cells. SARS-CoV-2 memory CD4 ${ }^{+} \mathrm{T}$ cells declined with an apparent $t_{1 / 2}$ of 94 days in the full cohort (Fig. $4 \mathrm{~B}$ ) and $t_{1 / 2}$ 64 days among 36 paired samples (Fig. 4C). The percentage of subjects with detectable circulating SARS-CoV-2 memory $\mathrm{CD}^{+}$T cells at 1 month PSO (20-50 days) was 93\% (53/57, Fig. $4 \mathrm{~B})$. The proportion of subjects positive for SARS-CoV-2 memory CD4 ${ }^{+} \mathrm{T}$ cells at $\geq 6$ months PSO was $92 \%(33 / 36)$.

Spike-specific and M-specific memory $\mathrm{CD}^{+} \mathrm{T}$ cells exhibited similar kinetics to the overall SARS-CoV-2-specific memory CD $4^{+} \mathrm{T}$ cells (whole cohort $t_{1 / 2} 139$ days and 153 days, respectively. Fig. 4, D and E, and fig. S4D). A plurality of the SARS-CoV-2 memory CD4 ${ }^{+} \mathrm{T}$ cells present at $\geq 6$ months PSO had a $\mathrm{T}_{\mathrm{CM}}$ phenotype (Fig. $4 \mathrm{~F}$ ).

$\mathrm{T}$ follicular helpers $\left(\mathrm{T}_{\mathrm{FH}}\right)$ are the specialized subset of $\mathrm{CD}^{+}$ $\mathrm{T}$ cells required for $\mathrm{B}$ cell help (57), and are therefore critical for the generation of neutralizing antibodies and long-lived humoral immunity in most contexts. Thus, we examined circulating $\mathrm{T}_{\mathrm{FH}}\left(\mathrm{cT}_{\mathrm{FH}}\right)$ memory $\mathrm{CD}^{+} \mathrm{T}$ cells, with particular interest in Spike-specific memory $\mathrm{cT}_{\mathrm{FH}}$ cells due to the importance of antibody responses against Spike. Memory $\mathrm{cT}_{\mathrm{FH}}$ cells specific for predicted epitopes across the remainder of the SARS-CoV-2 genome were also measured, using the MP_R megapool. Memory $\mathrm{cT}_{\mathrm{FH}}$ cells specific for SARS-CoV-2 Spike and MP_R were detected in the majority of COVID-19 cases at early time points (16/17. Fig. 4, H and I, and fig. S5, A to $\mathrm{D})$. $\mathrm{cT}_{\mathrm{FH}}$ memory appeared to be stable, with almost all subjects positive for Spike and MP_R memory $\mathrm{cT}_{\mathrm{FH}}$ cells at 6 months PSO (11/12 and 10/12, respectively. Fig. 4, H and I). Recently activated $\mathrm{cT}_{\mathrm{FH}}$ cells are PD-1 ${ }^{\text {hi }}$ (57). Consistent with conversion to resting memory $\mathrm{cT}_{\mathrm{FH}}$ cells, the percentage of PD-1 ${ }^{\text {hi }}$ SARS-CoV-2-specific memory $\mathrm{cT}_{\mathrm{FH}}$ dropped over time (Fig. 4J). CCR6 ${ }^{+}$SARS-CoV-2-specific $\mathrm{cT}_{\mathrm{FH}}$ cells have been associated with reduced COVID-19 disease severity (5) and have been reported to be a major fraction of Spike-specific $\mathrm{cT}_{\mathrm{FH}}$ cells in some studies $(5,50,58)$. Here we confirmed that a significant fraction of both Spike-specific and MP_R memory $\mathrm{cT}_{\mathrm{FH}}$ cells were $\mathrm{CCR}^{+}$. We also observed increases in $\mathrm{CCR} 6^{+}$ $\mathrm{cT}_{\mathrm{FH}}$ memory over time $(\mathrm{p}=0.001$ and $\mathrm{p}=0.014$ at $\geq 6$ months PSO compared to bulk c $\mathrm{T}_{\mathrm{FH}}$. Fig. $4 \mathrm{~K}$ ). Overall, substantial $\mathrm{cT}_{\mathrm{FH}}$ memory was observed after SARS-CoV-2 infection, with durability $\geq 6$ months PSO.

\section{Immune memory relationships}

Immune memory to SARS-CoV-2 were considered, including relationships between the compartments of immune memory. Males had higher Spike IgG (ANCOVA p=0.00018, Fig. 5A) and RBD and Nucleocapsid IgG (ANCOVA $\mathrm{p}=0.00077$ and $\mathrm{p}=0.018$, fig. S6, A and B), consistent with other studies $(46,47)$. Higher Spike IgG was also observed in males when only non-hospitalized cases were considered (ANCOVA $\mathrm{p}=0.00025$, fig. S6C). In contrast, no differences were observed in IgA or PSV neutralization titers (fig. S6, D to F), and no differences were detected in SARS-CoV-2 memory B cell, memory $\mathrm{CD}^{+} \mathrm{T}$ cell, or memory $\mathrm{CD}^{+} \mathrm{T}$ cell frequencies between males and females (fig. S6, G to K).

Immune memory was examined for associations between magnitude of memory and COVID-19 disease severity. The number of previously hospitalized COVID-19 cases $(n=13)$ limited analysis options. However, the cases were well distributed between males and females (Table 1), data from large numbers of non-hospitalized cases were available for comparison, and the analyses in Figs. 1 to 4 demonstrated that immune memory was relatively stable over the time window analyzed. Therefore, we could simplify the disease severity 
analysis by grouping all samples from 120+ days PSO [also limiting data to a single sample per subject (figs. S7to S9); most of the previously hospitalized subjects were sampled at two timepoints. fig. S7A] and then comparing non-hospitalized and hospitalized subjects. Spike and RBD IgG titers in hospitalized cases were higher than non-hospitalized cases (Fig. 5B), consistent with other studies $(46,47)$. Spike and RBD-specific memory B cell frequencies were also higher in hospitalized cases ( $\sim 1.7$-fold and $\sim 2.5$-fold, respectively. Fig. $5 \mathrm{C}$ and fig. S8). In contrast, memory $\mathrm{CD}^{+} \mathrm{T}$ cell frequencies were not higher in hospitalized cases compared to non-hospitalized cases (Fig. 5D and fig. S9) and memory CD4 ${ }^{+} \mathrm{T}$ cell frequencies trended lower in hospitalized cases compared to non-hospitalized cases (Fig. 5E and fig. S9). Therefore, while conclusions are limited by the number of hospitalized subjects, increased Spike IgG titers was consistent across three independent studies, and increased memory B cells among hospitalized cases were observed here (not measured in other studies), indicating that both compartments of long-term humoral immunity to SARS-CoV-2 are higher in individuals who experienced a more severe COVID-19 disease course. T cell memory did not follow the same pattern, consistent with indications that hospitalized cases of COVID-19 can be associated with poorer $\mathrm{T}$ cell responses in the acute phase $(5,59)$. Additionally, these data show that, while gender and COVID19 disease severity contribute to differences in immune memory to SARS-CoV-2, neither factor could account for the majority of the heterogeneity in immune memory to this virus.

Very few published data sets compare antigen-specific antibody, $\mathrm{B}$ cell, $\mathrm{CD}^{+} \mathrm{T}$ cell, and $\mathrm{CD}^{+}{ }^{+} \mathrm{T}$ cell memory to an acute viral infection in the same individuals. We therefore made use of this combined data set to examine interrelationships between compartments of immune memory. We focused on RBD IgG, RBD memory B cells, Spike IgA, total SARS-CoV-2specific $\mathrm{CD}^{+} \mathrm{T}$ cells, and total SARS-CoV-2-specific CD4 ${ }^{+} \mathrm{T}$ cells, due to their putative potential roles in protective immunity. The majority (64\%) of COVID-19 cases were positive for all five of these immune memory compartments at 1 to 2 months PSO (Fig. 5, F and G), with the incomplete responses largely reflecting individuals with no detectable $\mathrm{CD}^{+} \mathrm{T}$ cell memory and/or poor IgA responses (Fig. 5G). At 5 to 8 months after COVID-19, the proportion of individuals positive for all five of these immune memory compartments had dropped to $43 \%$; nevertheless, $95 \%$ of individuals were still positive for at least three out of five SARS-CoV-2 immune memory responses (Fig. $5 \mathrm{G}$ ). Immune memory at 5 to 8 months PSO represented contributions from different immune memory compartments in different individuals (Fig. $5 \mathrm{G}$ ). Similar results were obtained if RBD IgG was replaced by neutralizing antibodies (fig. S10A). Overall, these findings again highlight heterogeneity of immune memory, with different patterns of immune memory in different individuals.

Interrelationships between the components of memory were next examined by assessing ratios between immune memory compartments over time. The ratio of SARS-CoV-2 $\mathrm{CD}^{+}{ }^{+} \mathrm{T}$ cell memory to SARS-CoV-2 $\mathrm{CD}^{+} \mathrm{T}$ cell memory was largely stable over time (Fig. $5 \mathrm{H}$ and fig. S10B). Given that serological measurements are the simplest measurements of immune memory at a population scale, we examined how well such serological measurements may serve as surrogate markers of other components of SARS-CoV-2 immune memory over time. The relationship between circulating RBD IgG and RBD-specific memory B cells changed $\sim 20$-fold over the time range studied ( $\mathrm{R}=0.60$, Fig. $5 \mathrm{H}$ and fig. $\mathrm{S} 10 \mathrm{C})$. The changing relationship between circulating Spike IgA and RBD-specific memory B cells was even larger $(\mathrm{R}=0.55$, Fig. $5 \mathrm{H}$ and fig. S10D). The relationship between RBD IgG and SARSCoV-2 CD4 ${ }^{+} \mathrm{T}$ cell memory was relatively flat over the time range studied (Fig. $5 \mathrm{H}$ ); however, variation spanned a $~ 1000$ fold range (fig. S10E). Thus, predictive power of circulating RBD IgG for assessing T cell memory was poor because of the heterogeneity between individuals $(\mathrm{R}=0.046)$. In sum, while heterogeneity of immune responses is a defining feature of COVID-19, immune memory to SARS-CoV-2 develops in almost all subjects, with complex relationships between the individual immune memory compartments.

\section{Concluding remarks}

In this study, we aimed to fill gaps in our basic understanding of immune memory after COVID-19. This required simultaneous measurement of circulating antibodies, memory $B$ cells, CD8 ${ }^{+} \mathrm{T}$ cells, and $\mathrm{CD} 4^{+} \mathrm{T}$ cells specific for SARS-CoV-2, in a group of subjects with a full range of disease, and distributed from short time points after infection out to 8 months later. By studying these multiple compartments of adaptive immunity in an integrated manner, we observed that each component of SARS-CoV-2 immune memory exhibited distinct kinetics.

The Spike IgG titers were durable, with modest declines in titers at 6 to 8 months PSO at the population level. RBD IgG and SARS-CoV-2 PSV neutralizing antibody titers were potentially similarly stable, consistent with the RBD domain of Spike being the dominant neutralizing antibody target. We collected data at two time points for most longitudinal individuals herein. It is well recognized that the magnitude of the antibody response against SARS-CoV-2 is highly heterogeneous between individuals. We observed that heterogeneous initial antibody responses did not collapse into a homogeneous circulating antibody memory; rather, heterogeneity is also a central feature of immune memory to this virus. For antibodies, the responses spanned a $\sim 200$-fold range. Additionally, this heterogeneity means that long-term longitudinal studies 
will be required to precisely define antibody kinetics to SARSCoV-2. We are reporting the simplest statistical models that explain the data. These curve fits do not disprove more complex kinetics such as overlapping kinetics, but those models would require much denser longitudinal sampling in future studies. Biologically, IgG antibodies having a half-life of $\sim 21$ days, and the magnitude of the antibody response over time reflects antibodies produced first by short-lived plasma cells and then long-lived plasma cells, with affinity maturation also impacting the apparent magnitude in conventional binding assays and neutralization assays. Overall, at 5 to 8 months PSO, almost all individuals were positive for SARS-CoV-2 Spike and RBD IgG.

Notably, memory B cells specific for the Spike protein or RBD were detected in almost all COVID-19 cases, with no apparent half-life at 5 to 8 months post-infection. Other studies of RBD memory B cells are reporting similar findings $(50,60)$. $\mathrm{B}$ cell memory to some other infections has been observed to be long-lived, including $60+$ years after smallpox vaccination (61), or $90+$ years after infection with influenza (62). The memory T cell half-lives observed over $6+$ months PSO in this cohort ( 125-225 days for $\mathrm{CD}^{+}$and $\sim 94-153$ days for $\mathrm{CD} 4^{+} \mathrm{T}$ cells) were comparable to the 123 days $t_{1 / 2}$ observed for memory $\mathrm{CD}^{+} \mathrm{T}$ cells after yellow fever immunization (56). SARS-CoV-2 T cell memory at 6 months has also now been reported in another study (63). Notably, the durability of a fraction of the yellow fever virus-specific memory $\mathrm{CD} 8^{+} \mathrm{T}$ cells possessed an estimated $t_{1 / 2}$ of 485 days by deuterium labeling (56). Using different approaches, the long-term durability of memory $\mathrm{CD}^{+} \mathrm{T}$ cells to smallpox, over a period of many years, was an estimated $t_{1 / 2}$ of $\sim 10$ years $(61,64)$, which is also consistent with recent detection of SARS-CoV-T cells 17 years after the initial infection (65). These data suggest that $\mathrm{T}$ cell memory might reach a more stable plateau, or slower decay phase, beyond the first 8 months post-infection.

While immune memory is the source of long-term protective immunity, direct conclusions about protective immunity cannot be made on the basis of quantifying SARS-CoV-2 circulating antibodies, memory $\mathrm{B}$ cells, $\mathrm{CD} 8^{+} \mathrm{T}$ cells, and $\mathrm{CD} 4^{+}$ $\mathrm{T}$ cells, because mechanisms of protective immunity against SARS-CoV-2 or COVID-19 are not defined in humans. Nevertheless, some reasonable interpretations can be made. Antibodies are the only component of immune memory that can provide truly sterilizing immunity. Immunization studies in non-human primates have indicated that circulating neutralization titers of $\sim 200$ may provide sterilizing immunity against a relatively high dose URT challenge (66), and neutralizing titers of $\sim 3,400$ may provide sterilizing immunity against a very high dose URT challenge (67), although direct comparisons are not possible because the neutralizing antibody assays have not been standardized (3). Conclusions are also constrained by the limited overall amount of data on protective immunity to SARS-CoV-2.

Beyond sterilizing immunity, immune responses that confine SARS-CoV-2 to the URT and oral cavity would minimize COVID-19 disease severity to that of a 'common cold' or asymptomatic disease. This outcome is the primary goal of current COVID-19 vaccine clinical trials $(3,68)$. Such an outcome could potentially be mediated by a mixture of memory $\mathrm{CD}^{+} \mathrm{T}$ cells, memory $\mathrm{CD} 8^{+} \mathrm{T}$ cells, and memory B cells specific for RBD producing anamnestic neutralizing antibodies, based on mechanisms of action in mouse models of other viral infections (69-71). In human COVID-19 infections, SARS$\mathrm{CoV}$-2-specific $\mathrm{CD} 4^{+} \mathrm{T}$ cells and $\mathrm{CD} 8^{+} \mathrm{T}$ cells are associated with less COVID-19 disease severity during an ongoing SARSCoV-2 infection (5). Rapid seroconversion was associated with significantly reduced viral loads in acute disease over 14 days (29). Both of those associations are consistent with the hypothesis that SARS-CoV-2 memory $\mathrm{T}$ cells and B cells would be capable of substantially limiting SARS-CoV-2 dissemination and/or cumulative viral load, resulting in reduced COVID-19 disease severity. The likelihood of such outcomes is also closely tied to the kinetics of the infection, as memory $\mathrm{B}$ and $\mathrm{T}$ cell responses can take 3-5 days to successfully respond to an infection. As noted above, given the relatively slow course of severe COVID-19 in humans, resting immune memory compartments can potentially contribute in meaningful ways to protective immunity against pneumonia or severe secondary COVID-19. The presence of sub-sterilizing neutralizing antibody titers at the time of SARS-CoV-2 exposure would blunt the size of the initial infection, and may provide an added contribution to limiting COVID-19 severity, based on observations of protective immunity for other human respiratory viral infections $(37,72-74)$ and observations of SARS-CoV-2 vaccines in non-human primates $(48,67,75)$.

The current study has some limitations. Longitudinal data for each subject, with at least three time points per subject, would be required for more precise understanding of the kinetics of durability of SARS-CoV-2 antibodies. Nevertheless, the current cross-sectional data describe well the dynamics of SARS-CoV-2 memory B cells, $\mathrm{CD} 8^{+} \mathrm{T}$ cell, and $\mathrm{CD} 4^{+} \mathrm{T}$ cell over 8 months PSO. This study was not sufficiently powered to control for many variables simultaneously. Additionally, circulating memory was assessed here; it is possible that local URT immune memory is a minimal, moderate, or large component of immune memory after a primary infection with SARS-CoV-2. This remains to be determined.

Individual case reports show that reinfections with SARSCoV-2 are occurring $(76,77)$. However, a 2,800 person study found no symptomatic re-infections over a $\sim 118$ day window (78), and a 1,246 person study observed no symptomatic reinfections over 6 months (79). We observed heterogeneity in the magnitude of adaptive immune responses to SARS-CoV-2 persisting into the immune memory phase. It is therefore 
possible that a fraction of the SARS-CoV-2-infected population with low immune memory would become susceptible to re-infection relatively soon. While gender and disease severity both contribute some to the heterogeneity of immune memory reported here, the source of much of the heterogeneity in immune memory to SARS-CoV-2 is unknown and worth further examination. Perhaps heterogeneity derives from low cumulative viral load or a small initial inoculum in some individuals. Nevertheless, our data show immune memory in at least three immunological compartments was measurable in $\sim 95 \%$ of subjects 5 to 8 months PSO, indicating that durable immunity against secondary COVID-19 disease is a possibility in most individuals.

\section{Materials and methods \\ Human subjects}

The Institutional Review Boards of the University of California, San Diego (UCSD; 200236X) and the La Jolla Institute for Immunology (LJI; VD-214) approved the protocols used for blood collection for subjects with COVID-19 who donated at all sites other than Mt. Sinai. The Icahn School of Medicine at Mt. Sinai IRB approved the samples collected at this institution in New York City (IRB-16-00791). All human subjects were assessed for medical decision-making capacity using a standardized, approved assessment, and voluntarily gave informed consent prior to being enrolled in the study. Study inclusion criteria included a diagnosis of COVID-19 or suspected COVID-19, age of 18 years or greater, willingness and ability to provide informed consent. Although not a strict inclusion criterion, evidence of positive PCR-based testing for SARS-CoV-2 was requested from subjects prior to participation. 145 cases were confirmed SARS-CoV-2 positive by PCRbased testing (Table 1). Two subjects tested negative by SARSCoV-2 PCR (Table 1). The remainder were not tested or did not have test results available for review (Table 1). Subjects who had a medical history and/or symptoms consistent with COVID-19, but lacked positive PCR-based testing for SARSCoV-2 and subsequently had negative laboratory-based serologic testing for SARS-CoV-2 were then excluded; i.e., all COVID-19 cases in this study were confirmed cases by SARSCoV-2 PCR or SARS-CoV-2 serodiagnostics, or both. Adults of all races, ethnicities, ages, and genders were eligible to participate. Study exclusion criteria included lack of willingness to participate, lack of ability to provide informed consent, or a medical contraindication to blood donation (e.g., severe anemia). Subject samples at LJI were obtained from individuals in California and at least seven other states.

Blood collection and processing methods at LJI were performed as previously described (5). Briefly, whole blood was collected via phlebotomy in acid citrate dextrose (ACD) serum separator tubes (SST), or ethylenediaminetetraacetic acid (EDTA) tubes and processed for peripheral blood mononuclear cells (PBMC), serum, and plasma isolation. Most donors were screened for symptoms prior to scheduling blood draws, and had to be symptom-free and approximately $3-4$ weeks out from symptom onset at the time of the initial blood draw at UCSD or LJI, respectively. Samples were coded, and then de-identified prior to analysis. Other efforts to maintain the confidentiality of participants included the labeling samples with coded identification numbers. An overview of the characteristics of subjects with COVID-19 is provided in Table 1.

COVID-19 disease severity was scored from 0 to 10 using a numerical scoring system based on the NIH ordinal scale $(5,80)$. A categorical descriptor was applied based on this scoring system: "asymptomatic" for a score of 1 , "mild" for a score of 2-3, "moderate" for a score of 4-5, and "severe" for a score of 6 or more. Subjects with a numerical score of 4 or higher required hospitalization (including admission for observation) for management of COVID-19. Only one of 13 hospitalized subjects is shared from the previous study of acute COVID-19 (5). The days PSO was determined based on the difference between the date of the blood collection and the date of first reported symptoms consistent with COVID-19. For asymptomatic subjects, the day from first positive SARSCoV-2 PCR-based testing was used in place of the date of first reported COVID-19 symptoms.

\section{Recombinant proteins}

Stabilized Spike protein (2P, (81)) and the receptor binding domain (RBD) were expressed in HEK293F cells. Briefly, DNA expressing stabilized spike protein and RBD were subcloned into separate phCMV vectors and transfected into HEK293F cells at a ratio of $1 \mathrm{mg}$ of DNA to $1 \mathrm{~L}$ of cells. The cells were cultured at $37 \mathrm{C}$ in a shaker incubator set to $125 \mathrm{rpm}$, $80 \%$ humidity and $8 \% \mathrm{CO}_{2}$. When cell viability dropped below $80 \%$ (typically 4-5 days), media was harvested and centrifuged to remove cells. Biolock reagent was added to the supernatant media to remove any excess biotin. The media was then filtered through a $0.22 \mathrm{um}$ filter to remove Biolocked-aggregates. Proteins were purified using Streptrap HP $5 \mathrm{~mL}$ columns (Cytiva) using $100 \mathrm{mM}$ Tris, $100 \mathrm{mM} \mathrm{NaCl}$ as the Wash Buffer and $100 \mathrm{mM}$ Tris, $100 \mathrm{mM} \mathrm{NaCl}, 2.5 \mathrm{mM}$ d-Desthiobiotin as the Elution Buffer. The eluted fractions for Spike proteins were concentrated on $100 \mathrm{kDa}$ Amicon filters while the RBD were concentrated on $10 \mathrm{kDa}$ filters. The samples were further purified using S6increase columns for the spike variants and S200increase column for RBD.

\section{SARS-COV-2 ELISAS}

SARS-CoV-2 ELISAs were performed as previously described $(2,5,82)$. Briefly, Corning 96 -well half area plates (ThermoFisher 3690) were coated with $1 \mu \mathrm{g} / \mathrm{mL}$ of antigen overnight at $4^{\circ} \mathrm{C}$. Antigens included recombinant SARS-CoV-2 
RBD protein, recombinant Spike protein, and recombinant Nucleocapsid protein (GenScript Z03488) (Recombinant nucleocapsid antigens were also tested from Sino Biological (40588-V07E) and Invivogen (his-sars2-n) and yielded comparable results to GenScript nucleocapsid). The following day, plates were blocked with $3 \%$ milk in phosphate buffered saline (PBS) containing $0.05 \%$ Tween-20 for 1.5 hours at room temperature. Plasma was heat inactivated at $56^{\circ} \mathrm{C}$ for $30-60$ min. Plasma was diluted in $1 \%$ milk containing $0.05 \%$ Tween20 in PBS starting at a 1:3 dilution followed by serial dilutions by 3 and incubated for 1.5 hours at room temperature. Plates were washed 5 times with $0.05 \%$ PBS-Tween-20. Secondary antibodies were diluted in $1 \%$ milk containing $0.05 \%$ Tween20 in PBS. For IgG, anti-human IgG peroxidase antibody produced in goat (Sigma A6029) was used at a 1:5,000 dilution. For IgA, anti-human IgA horseradish peroxidase antibody (Hybridoma Reagent Laboratory HP6123-HRP) was used at a 1:1,000 dilution. The HP6123 monoclonal anti-IgA was used because of its CDC and WHO validated specificity for human IgA1 and IgA2 and lack of crossreactivity with non-IgA isotypes (83).

Endpoint titers were plotted for each sample, using background subtracted data. Negative and positive controls were used to standardize each assay and normalize across experiments. A positive control standard was created by pooling plasma from 6 convalescent COVID-19 donors to normalize between experiments. The limit of detection (LOD) was defined as 1:3 for IgG, 1:10 for IgA. Limit of sensitivity (LOS) for SARS-CoV-2 infected individuals was established based on uninfected subjects, using plasma from normal healthy donors never exposed to SARS-CoV-2. For cross-sectional analyses, modeling for the best fit curve (e.g., one phase decay versus simple linear regression) was performed using GraphPad Prism 8.0. Best curve fit was defined by an extra sum-of-squares F Test, selecting the simpler model unless $\mathrm{P}$ $<0.05$ (84). Continuous decay (linear regression), one-phased decay, or two-phased decay of log data were assessed in all cases, with the best fitting statistical model chosen based on the F test; in several cases a quadratic equation fit was also considered. To calculate the $t_{1 / 2}, \log _{2}$ transformed data was utilized. Using the best fit curve, either a one phase decay non-linear fit or a simple linear regression (continuous decay) was utilized. For simple linear regressions, Pearson $\mathrm{R}$ was calculated for correlation using $\log _{2}$ transformed data. For one phase decay non-linear fit, $\mathrm{R}$ was reported. For longitudinal samples, a simple linear regression was performed, with $t_{1 / 2}$ calculated from $\log _{2}$ transformed data for each pair. For gender analyses, modeling and $t_{1 / 2}$ was performed similar to cross-sectional analyses; ANCOVA (VassarStats or GraphPad Prism 8.4) was then performed between male and female data sets. ANCOVA p-values of the adjusted means were reported and considered significant if the test for homogeneity of regressions was not significant.

\section{Neutralizing antibody assays}

The pseudovirus neutralizing antibody assay was performed as previously described (5). Briefly, Vero cells were seeded in 96-well plates to produce a monolayer at the time of infection. Pre-titrated amounts of rVSV-SARS-Cov-2 (phCMV3SARS-CoV-2 Spike SARS-CoV-2-pseduotyped VSV- $\triangle$ G-GFP were generated by transfecting HEK293T cells, ATCC CRL3216) were incubated with serially diluted human plasma at $37^{\circ} \mathrm{C}$ for 1 hour before addition to confluent Vero cell monolayers (ATCC CCL-81) in 96-well plates. Cells were incubated for $12-16$ hours at $37^{\circ} \mathrm{C}$ in $5 \% \mathrm{CO}_{2}$. Cells were then fixed in $4 \%$ paraformaldehyde, stained with $1 \mu \mathrm{g} / \mathrm{mL}$ Hoechst, and imaged using a CellInsight CX5 imager to quantify the total number of cells expressing GFP. Infection was normalized to the average number of cells infected with rVSV-SARS-CoV-2 incubated with normal human plasma. The limit of detection (LOD) was established as < 1:20 based on plasma samples from a series of unexposed control subjects. Negative signals were set to 1:19. Neutralization IC50 titers were calculated using One-Site Fit LogIC50 regression in GraphPad Prism 8.0.

\section{Detection of antigen-specific memory $B$ cells}

To detect SARS-CoV-2 specific B cells, biotinylated protein antigens were individually multimerized with fluorescently labeled streptavidin at $4^{\circ} \mathrm{C}$ for one hour. Full-length SARSCoV-2 Spike (2P-stabilized, double Strep-tagged) and RBD were generated in-house. Biotinylation was performed using biotin-protein ligase standard reaction kit (Avidity, Cat\# Bir500A) following the manufacturer's standard protocol and dialyzed overnight against PBS. Biotinylated Spike was mixed with streptavidin BV421 (BioLegend, Cat\# 405225) and streptavidin Alexa Fluor 647 (Thermo Fisher Scientific, Cat\# S21374) at 20:1 ratio ( 6:1 molar ratio). Biotinylated RBD was mixed with streptavidin PE/Cyanine7 (BioLegend, Cat\# $405206)$ at 2.2:1 ratio ( 4:1 molar ratio). Biotinylated SARSCoV-2 full length Nucleocapsid (Avi- and His-tagged; Sino Biological, Cat\# 40588-V27B-B) was multimerized using streptavidin PE (BioLegend, Cat\# 405204) and streptavidin BV711 (BioLegend, Cat\# 405241) at 5.5:1 ratio ( 6:1 molar ratio). Streptavidin PE/Cyanine5.5 (Thermo Fisher Scientific, Cat\# SA1018) was used as a decoy probe to gate out SARS-CoV-2 non-specific streptavidin-binding B cells. The antigen probes prepared individually as above were then mixed in Brilliant Buffer (BD Bioscience, Cat\# 566349) containing $5 \mu \mathrm{M}$ free dbiotin (Avidity, Cat\# Bir500A). Free d-biotin ensured minimal cross-reactivity of antigen probes. $\sim 10^{7}$ previously frozen PBMC samples were prepared in U-bottom 96-well plates and stained with $50 \mu \mathrm{L}$ antigen probe cocktail containing 100ng Spike per probe (total 200ng), 27.5ng RBD, 40ng 
Nucleocapsid per probe (total 80ng) and 20ng streptavidin $\mathrm{PE} / \mathrm{Cyanine} 5.5$ at $4^{\circ} \mathrm{C}$ for one hour to ensure maximal staining quality before surface staining with antibodies as listed in table S1 was performed in Brilliant Buffer at $4^{\circ} \mathrm{C}$ for $30 \mathrm{~min}$. Dead cells were stained using LIVE/DEAD Fixable Blue Stain Kit (Thermo Fisher Scientific, Cat\# L34962) in DPBS at $4{ }^{\circ} \mathrm{C}$ for $30 \mathrm{~min}$. $\sim 80 \%$ of antigen-specific memory $\left(\mathrm{IgD}^{-}\right.$and/or $\mathrm{CD} 27^{+}$) B cells detected using this method were $\mathrm{IgM}^{+}, \mathrm{IgG}^{+}$, or IgM $^{-}$IgG- $^{-}$IgA $^{+}$, which were comparable to non-specific memory B cells. Based on these observations, we concluded that the antigen probes did not significantly impact the quality of surface immunoglobulin staining. Stained PBMC samples were acquired on Cytek Aurora and analyzed using FlowJo10.7.1 (BD Bioscience).

The frequency of antigen-specific memory B cells was expressed as a percentage of total B cells $\left(\mathrm{CD} 19^{+} \mathrm{CD} 20^{+} \mathrm{CD} 38^{\mathrm{int} /-}\right.$ , CD3 ${ }^{-}, \mathrm{CD}_{4}^{-}, \mathrm{CD}^{-}{ }^{-}, \mathrm{CD}^{-} 6^{-}, \mathrm{LIVE} \mathrm{DEAD}^{-}$, lymphocytes), or as number per $10^{6} \mathrm{PBMC}$ (LIVE/DEAD- cells). LOD was set based on median $+2 \times$ standard deviation (SD) of [1 / (number of total $\mathrm{B}$ cells recorded)] or median $+2 \times \mathrm{SD}$ of $\left[10^{6} /\right.$ (number of PBMC recorded)]. LOS was set as the median + $2 \times$ SD of the results in unexposed donors. Phenotype analysis of antigen-specific B cells was performed only in subjects with at least 10 cells detected in the respective antigen-specific memory $\mathrm{B}$ cell gate. In each experiment, PBMC from a known positive control (COVID-19 convalescent subject) and unexposed subjects were included to ensure consistent sensitivity and specificity of the assay. For each data set, second order polynomial, simple linear regression, and pseudo-first order kinetic models were considered. The model with a lower Akaike's Information Criterion value was determined to be a better-fit and visualized.

\section{Activation induced markers (AIM) T cell assay}

Antigen-specific $\mathrm{CD} 4^{+} \mathrm{T}$ cells were measured as a percentage of $\mathrm{AIM}^{+}\left(\mathrm{OX} 40^{+} \mathrm{CD} 137^{+}\right) \mathrm{CD}^{+} \mathrm{T}$ and $\left(\mathrm{CD} 69^{+} \mathrm{CD} 137^{+}\right) \mathrm{CD}^{+} \mathrm{T}$ cells after stimulation of PBMC with overlapping peptide megapools (MP) spanning the entire SARS-CoV-2 ORFeome, as previously described (2). Cells were cultured for 24 hours in the presence of SARS-CoV-2 specific MPs $[1 \mu \mathrm{g} / \mathrm{mL}]$ or 5 $\mu \mathrm{g} / \mathrm{mL}$ phytohemagglutinin (PHA, Roche) in 96-wells U-bottom plates at $1 \times 10^{6} \mathrm{PBMC}$ per well. A stimulation with an equimolar amount of DMSO was performed as a negative control, PHA, and stimulation with a combined $\mathrm{CD}^{+}$and $\mathrm{CD}^{+}$cytomegalovirus epitope $\mathrm{MP}(\mathrm{CMV}, 1 \mu \mathrm{g} / \mathrm{mL})$ were included as positive controls. Any sample with low PHA signal was excluded as a quality control.

Antigen-specific $\mathrm{CD}^{+}$and $\mathrm{CD}^{+}{ }^{+} \mathrm{T}$ cells were measured as background (DMSO) subtracted data, with a minimal DMSO level set to $0.005 \%$. All positive ORFs (> 0.02\% for $\mathrm{CD}^{+}$, > $0.05 \%$ for $\mathrm{CD}^{+}$) were then aggregated into a combined sum of SARS-CoV-2-specific $\mathrm{CD}^{+}{ }^{+}$or $\mathrm{CD}^{+}{ }^{+} \mathrm{T}$ cells. The threshold for positivity for antigen-specific $\mathrm{CD}^{+} \mathrm{T}$ cell responses $(0.03 \%)$ and antigen-specific $\mathrm{CD}^{+} \mathrm{T}$ cell responses $(0.12 \%)$ was calculated using the median two-fold standard deviation of all negative controls measured ( $>150)$. The antibody panel utilized in the $\left(\mathrm{OX} 40^{+} \mathrm{CD} 137^{+}\right) \mathrm{CD}^{+} \mathrm{T}$ and $\left(\mathrm{CD} 69^{+} \mathrm{CD} 137^{+}\right)$ $\mathrm{CD}^{+} \mathrm{T}$ cells AIM staining is shown in table $\mathrm{S} 2$. A consistency analysis was performed for multiple measurements of AIM T cell assays by two different operators. Before merging, we compared the protein immunodominance, total SARS-CoV-2specific $\mathrm{CD}^{+}$and $\mathrm{CD}^{+} \mathrm{T}$ cell responses, and half-life calculations between the two groups of experimental data. In longitudinal analyses, half-life calculations excluded any samples that were negative at both timepoints (since a halflife could not be calculated), though all data were included in the graphs.

For surface $\mathrm{CD} 40 \mathrm{~L}^{+} \mathrm{OX} 40^{+} \mathrm{CD}^{+} \mathrm{T}$ cell AIM assays, experiments were performed as previously described (5), with the following modifications. Cells were cultured in complete RPMI containing 5\% human AB serum (Gemini Bioproducts), beta-mercaptoethanol, Penicillin/Streptomycin, sodium pyruvate (NaPy), and non-essential amino acids. Prior to addition of peptide MPs, cells were blocked at $37^{\circ} \mathrm{C}$ for $15 \mathrm{~min}$ with $0.5 \mu \mathrm{g} / \mathrm{mL}$ anti-CD40 mAb (Miltenyi Biotec). A stimulation with an equimolar amount of DMSO was performed to determine background subtraction, and activation from Staphylococcal enterotoxin B (SEB) at $1 \mu \mathrm{g} / \mathrm{mL}$ was used as (positive) quality control. LOD for antigen-specific $\mathrm{cT}_{\mathrm{FH}}$ among $\mathrm{CD}^{+} \mathrm{T}$ cells was based on the LOD for antigen-specific $\mathrm{CD} 4^{+} \mathrm{T}$ cells (described above) multiplied by the average $\% \mathrm{cT}_{\mathrm{FH}}$ in the bulk CD4 $\mathrm{T}$ cells among control samples. An inclusion threshold of ten events after the $\mathrm{cT}_{\mathrm{FH}} \mathrm{CXCR}^{+}$gate was used for PD- $1^{\text {hi }}$ and $\mathrm{CCR} 6^{+}$calculations, and Mann-Whitney nonparametric and Wilcoxon signed-rank statistical tests were applied for the respective comparisons.

\section{REFERENCES AND NOTES}

1. D. S. Stephens, M. J. McElrath, COVID-19 and the Path to Immunity. JAMA 324 1279-1281 (2020). doi:10.1001/jama.2020.16656 Medline

2. A. Grifoni, D. Weiskopf, S. I. Ramirez, J. Mateus, J. M. Dan, C. R. Moderbacher, S. A. Rawlings, A. Sutherland, L. Premkumar, R. S. Jadi, D. Marrama, A. M. de Silva, A. Frazier, A. F. Carlin, J. A. Greenbaum, B. Peters, F. Krammer, D. M. Smith, S. Crotty, A. Sette, Targets of T Cell Responses to SARS-CoV-2 Coronavirus in Humans with COVID-19 Disease and Unexposed Individuals. Cell 181, 14891501.e15 (2020). doi:10.1016/i.cell.2020.05.015 Medline

3. F. Krammer, SARS-CoV-2 vaccines in development. Nature 586, 516-527 (2020). doi:10.1038/s41586-020-2798-3 Medline

4. M. S. Suthar, M. G. Zimmerman, R. C. Kauffman, G. Mantus, S. L. Linderman, W. H. Hudson, A. Vanderheiden, L. Nyhoff, C. W. Davis, O. Adekunle, M. Affer, M. Sherman, S. Reynolds, H. P. Verkerke, D. N. Alter, J. Guarner, J. Bryksin, M. C. Horwath, C. M. Arthur, N. Saakadze, G. H. Smith, S. Edupuganti, E. M. Scherer, K. Hellmeister, A. Cheng, J. A. Morales, A. S. Neish, S. R. Stowell, F. Frank, E. Ortlund, E. J. Anderson, V. D. Menachery, N. Rouphael, A. K. Mehta, D. S. Stephens, R. Ahmed, J. D. Roback, J. Wrammert, Rapid generation of neutralizing antibody responses in COVID-19 patients. Cell Rep. Med. 1, 100040 (2020). doi:10.1016/i.xcrm.2020.100040 Medline

5. C. Rydyznski Moderbacher, S. I. Ramirez, J. M. Dan, A. Grifoni, K. M. Hastie, D. Weiskopf, S. Belanger, R. K. Abbott, C. Kim, J. Choi, Y. Kato, E. G. Crotty, C. Kim, 
S. A. Rawlings, J. Mateus, L. P. V. Tse, A. Frazier, R. Baric, B. Peters, J. Greenbaum, E. Ollmann Saphire, D. M. Smith, A. Sette, S. Crotty, Antigen-specific adaptive immunity to SARS-CoV-2 in acute COVID-19 and associations with age and disease severity. Cell 183, 996-1012.e19 (2020). doi:10.1016/i.cell.2020.09.038 Medline

6. R. Zhou, K. K.-W. To, Y.-C. Wong, L. Liu, B. Zhou, X. Li, H. Huang, Y. Mo, T.-Y. Luk, T. T.-K. Lau, P. Yeung, W.-M. Chan, A. K.-L. Wu, K.-C. Lung, O. T.-Y. Tsang, W.-S. Leung, I. F.-N. Hung, K.-Y. Yuen, Z. Chen, Acute SARS-CoV-2 infection impairs dendritic cell and $\mathrm{T}$ cell responses. Immunity 53, 864-877.e5 (2020). doi:10.1016/i.immuni.2020.07.026 Medline

7. M. Liao, Y. Liu, J. Yuan, Y. Wen, G. Xu, J. Zhao, L. Cheng, J. Li, X. Wang, F. Wang, L. Liu, I. Amit, S. Zhang, Z. Zhang, Single-cell landscape of bronchoalveolar immune cells in patients with COVID-19. Nat. Med. 26, 842-844 (2020). doi:10.1038/s41591-020-0901-9 Medline

8. A. G. Laing, A. Lorenc, I. Del Molino Del Barrio, A. Das, M. Fish, L. Monin, M. MuñozRuiz, D. R. McKenzie, T. S. Hayday, I. Francos-Quijorna, S. Kamdar, M. Joseph, D. Davies, R. Davis, A. Jennings, I. Zlatareva, P. Vantourout, Y. Wu, V. Sofra, F. Cano, M. Greco, E. Theodoridis, J. D. Freedman, S. Gee, J. N. E. Chan, S. Ryan, E. BugalloBlanco, P. Peterson, K. Kisand, L. Haljasmägi, L. Chadli, P. Moingeon, L. Martinez, B. Merrick, K. Bisnauthsing, K. Brooks, M. A. A. Ibrahim, J. Mason, F. Lopez Gomez, K. Babalola, S. Abdul-Jawad, J. Cason, C. Mant, J. Seow, C. Graham, K. J. Doores, F. Di Rosa, J. Edgeworth, M. Shankar-Hari, A. C. Hayday, A dynamic COVID-19 immune signature includes associations with poor prognosis. Nat. Med. 26, 16231635 (2020). doi:10.1038/s41591-020-1038-6 Medline

9. D. Blanco-Melo, B. E. Nilsson-Payant, W.-C. Liu, S. Uhl, D. Hoagland, R. Møller, T. X. Jordan, K. Oishi, M. Panis, D. Sachs, T. T. Wang, R. E. Schwartz, J. K. Lim, R. A. Albrecht, B. R. tenOever, Imbalanced Host Response to SARS-CoV-2 Drives Development of COVID-19. Cell 181, 1036-1045.e9 (2020). doi:10.1016/i.cell.2020.04.026 Medline

10. P. S. Arunachalam, F. Wimmers, C. K. P. Mok, R. A. P. M. Perera, M. Scott, T. Hagan, N. Sigal, Y. Feng, L. Bristow, O. Tak-Yin Tsang, D. Wagh, J. Coller, K. L. Pellegrini, D. Kazmin, G. Alaaeddine, W. S. Leung, J. M. C. Chan, T. S. H. Chik, C. Y. C. Choi, C. Huerta, M. Paine McCullough, H. Lv, E. Anderson, S. Edupuganti, A. A. Upadhyay, S. E. Bosinger, H. T. Maecker, P. Khatri, N. Rouphael, M. Peiris, B. Pulendran, Systems biological assessment of immunity to mild versus severe COVID-19 infection in humans. Science 369, 1210-1220 (2020). doi:10.1126/science.abc6261 Medline

11. P. Bastard, L. B. Rosen, Q. Zhang, E. Michailidis, H.-H. Hoffmann, Y. Zhang, K. Dorgham, Q. Philippot, J. Rosain, V. Béziat, J. Manry, E. Shaw, L. Haljasmägi, P. Peterson, L. Lorenzo, L. Bizien, S. Trouillet-Assant, K. Dobbs, A. A. de Jesus, A. Belot, A. Kallaste, E. Catherinot, Y. Tandjaoui-Lambiotte, J. Le Pen, G. Kerner, B. Bigio, Y. Seeleuthner, R. Yang, A. Bolze, A. N. Spaan, O. M. Delmonte, M. S. Abers, A. Aiuti, G. Casari, V. Lampasona, L. Piemonti, F. Ciceri, K. Bilguvar, R. P. Lifton, M. Vasse, D. M. Smadja, M. Migaud, J. Hadjadj, B. Terrier, D. Duffy, L. Quintana-Murci, D. van de Beek, L. Roussel, D. C. Vinh, S. G. Tangye, F. Haerynck, D. Dalmau, J. Martinez-Picado, P. Brodin, M. C. Nussenzweig, S. Boisson-Dupuis, C. RodríguezGallego, G. Vogt, T. H. Mogensen, A. J. Oler, J. Gu, P. D. Burbelo, J. I. Cohen, A. Biondi, L. R. Bettini, M. D'Angio, P. Bonfanti, P. Rossignol, J. Mayaux, F. RieuxLaucat, E. S. Husebye, F. Fusco, M. V. Ursini, L. Imberti, A. Sottini, S. Paghera, E. Quiros-Roldan, C. Rossi, R. Castagnoli, D. Montagna, A. Licari, G. L. Marseglia, X. Duval, J. Ghosn, J. S. Tsang, R. Goldbach-Mansky, K. Kisand, M. S. Lionakis, A. Puel, S. Y. Zhang, S. M. Holland, G. Gorochov, E. Jouanguy, C. M. Rice, A. Cobat, L. D. Notarangelo, L. Abel, H. C. Su, J. L. Casanova; HGID Lab; NIAID-USUHS Immune Response to COVID Group; COVID Clinicians; COVID-STORM Clinicians; Imagine COVID Group; French COVID Cohort Study Group; Milieu Intérieur Consortium; CoV-Contact Cohort; Amsterdam UMC Covid-19 Biobank; COVID Human Genetic Effort, Autoantibodies against type I IFNs in patients with life-threatening COVID19. Science 370, eabd4585 (2020). doi:10.1126/science.abd4585 Medline

12. Q. Zhang, P. Bastard, Z. Liu, J. Le Pen, M. Moncada-Velez, J. Chen, M. Ogishi, I. K. D. Sabli, S. Hodeib, C. Korol, J. Rosain, K. Bilguvar, J. Ye, A. Bolze, B. Bigio, R. Yang, A. A. Arias, Q. Zhou, Y. Zhang, F. Onodi, S. Korniotis, L. Karpf, Q. Philippot, M. Chbihi, L. Bonnet-Madin, K. Dorgham, N. Smith, W. M. Schneider, B. S. Razooky, H.-H. Hoffmann, E. Michailidis, L. Moens, J. E. Han, L. Lorenzo, L. Bizien, P. Meade, A.-L. Neehus, A. C. Ugurbil, A. Corneau, G. Kerner, P. Zhang, F. Rapaport, Y. Seeleuthner, J. Manry, C. Masson, Y. Schmitt, A. Schlüter, T. Le Voyer, T. Khan, J.
Li, J. Fellay, L. Roussel, M. Shahrooei, M. F. Alosaimi, D. Mansouri, H. Al-Saud, F. Al-Mulla, F. Almourfi, S. Z. Al-Muhsen, F. Alsohime, S. Al Turki, R. Hasanato, D. van de Beek, A. Biondi, L. R. Bettini, M. D'Angio', P. Bonfanti, L. Imberti, A. Sottini, S. Paghera, E. Quiros-Roldan, C. Rossi, A. J. Oler, M. F. Tompkins, C. Alba, I. Vandernoot, J.-C. Goffard, G. Smits, I. Migeotte, F. Haerynck, P. Soler-Palacin, A. Martin-Nalda, R. Colobran, P.-E. Morange, S. Keles, F. Çölkesen, T. Ozcelik, K. K. Yasar, S. Senoglu, S.. N. Karabela, C. Rodríguez-Gallego, G. Novelli, S. Hraiech, Y. Tandjaoui-Lambiotte, X. Duval, C. Laouénan, A. L. Snow, C. L. Dalgard, J. D. Milner, D. C. Vinh, T. H. Mogensen, N. Marr, A. N. Spaan, B. Boisson, S. Boisson-Dupuis, J. Bustamante, A. Puel, M. J. Ciancanelli, I. Meyts, T. Maniatis, V. Soumelis, A. Amara, M. Nussenzweig, A. García-Sastre, F. Krammer, A. Pujol, D. Duffy, R. P. Lifton, S. Y. Zhang, G. Gorochov, V. Béziat, E. Jouanguy, V. Sancho-Shimizu, C. M. Rice, L. Abel, L. D. Notarangelo, A. Cobat, H. C. Su, J. L. Casanova; COVID-STORM Clinicians; COVID Clinicians; Imagine COVID Group; French COVID Cohort Study Group; CoV-Contact Cohort; Amsterdam UMC Covid-19 Biobank; COVID Human Genetic Effort; NIAID-USUHS/TAGC COVID Immunity Group, Inborn errors of type I IFN immunity in patients with life-threatening COVID-19. Science 370, eabd4570 (2020). doi:10.1126/science.abd4570 Medline

13. D. M. Del Valle, S. Kim-Schulze, H.-H. Huang, N. D. Beckmann, S. Nirenberg, B. Wang, Y. Lavin, T. H. Swartz, D. Madduri, A. Stock, T. U. Marron, H. Xie, M. Patel, K. Tuballes, O. Van Oekelen, A. Rahman, P. Kovatch, J. A. Aberg, E. Schadt, S. Jagannath, M. Mazumdar, A. W. Charney, A. Firpo-Betancourt, D. R. Mendu, J. Jhang, D. Reich, K. Sigel, C. Cordon-Cardo, M. Feldmann, S. Parekh, M. Merad, S. Gnjatic, An inflammatory cytokine signature predicts COVID-19 severity and survival. Nat. Med. 26, 1636-1643 (2020). doi:10.1038/s41591-020-1051-9 Medline

14. L. Kuri-Cervantes, M. B. Pampena, W. Meng, A. M. Rosenfeld, C. A. G. Ittner, A. R. Weisman, R. S. Agyekum, D. Mathew, A. E. Baxter, L. A. Vella, O. Kuthuru, S. A. Apostolidis, L. Bershaw, J. Dougherty, A. R. Greenplate, A. Pattekar, J. Kim, N. Han, S. Gouma, M. E. Weirick, C. P. Arevalo, M. J. Bolton, E. C. Goodwin, E. M. Anderson, S. E. Hensley, T. K. Jones, N. S. Mangalmurti, E. T. Luning Prak, E. J. Wherry, N. J. Meyer, M. R. Betts, Comprehensive mapping of immune perturbations associated with severe COVID-19. Sci. Immunol. 5, eabd7114 (2020). doi:10.1126/sciimmunol.abd7114 Medline

15. S. Li, L. Jiang, X. Li, F. Lin, Y. Wang, B. Li, T. Jiang, W. An, S. Liu, H. Liu, P. Xu, L. Zhao, L. Zhang, J. Mu, H. Wang, J. Kang, Y. Li, L. Huang, C. Zhu, S. Zhao, J. Lu, J. $\mathrm{Ji}$, J. Zhao, Clinical and pathological investigation of patients with severe COVID19. JCl Insight 5, (2020). doi:10.1172/jci.insight.138070 Medline

16. C. Radermecker, N. Detrembleur, J. Guiot, E. Cavalier, M. Henket, C. d'Emal, C. Vanwinge, D. Cataldo, C. Oury, P. Delvenne, T. Marichal, Neutrophil extracellular traps infiltrate the lung airway, interstitial, and vascular compartments in severe COVID-19. J. Exp. Med. 217, e20201012 (2020). doi:10.1084/jem.20201012 Medline

17. B. Schurink, E. Roos, T. Radonic, E. Barbe, C. S. C. Bouman, H. H. de Boer, G. J. de Bree, E. B. Bulle, E. M. Aronica, S. Florquin, J. Fronczek, L. M. A. Heunks, M. D. de Jong, L. Guo, R. du Long, R. Lutter, P. C. G. Molenaar, E. A. Neefjes-Borst, H. W. M. Niessen, C. J. M. van Noesel, J. J. T. H. Roelofs, E. J. Snijder, E. C. Soer, J. Verheij, A. P. J. Vlaar, W. Vos, N. N. van der Wel, A. C. van der Wal, P. van der Valk, M. Bugiani, Viral presence and immunopathology in patients with lethal COVID-19: A prospective autopsy cohort study. Lancet Microbe 1, e290-e299 (2020). doi:10.1016/S2666-5247(20)30144-0 Medline

18. M. Aid, K. Busman-Sahay, S. J. Vidal, Z. Maliga, S. Bondoc, C. Starke, M. Terry, C. A. Jacobson, L. Wrijil, S. Ducat, O. R. Brook, A. D. Miller, M. Porto, K. L. Pellegrini, M. Pino, T. N. Hoang, A. Chandrashekar, S. Patel, K. Stephenson, S. E. Bosinger, H. Andersen, M. G. Lewis, J. L. Hecht, P. K. Sorger, A. J. Martinot, J. D. Estes, D. H. Barouch, Vascular Disease and Thrombosis in SARS-CoV-2-Infected Rhesus Macaques. Cell 183, 1354-1366.e13 (2020). doi:10.1016/i.cell.2020.10.005 Medline

19. N. Baumgarth, J. Nikolich-Žugich, F. E.-H. Lee, D. Bhattacharya, Antibody Responses to SARS-CoV-2: Let's Stick to Known Knowns. J. Immunol. 205, 23422350 (2020). doi:10.4049/jimmunol.2000839 Medline

20. A. Wajnberg, F. Amanat, A. Firpo, D. R. Altman, M. J. Bailey, M. Mansour, M. McMahon, P. Meade, D. R. Mendu, K. Muellers, D. Stadlbauer, K. Stone, S. Strohmeier, V. Simon, J. Aberg, D. L. Reich, F. Krammer, C. Cordon-Cardo, Robust neutralizing antibodies to SARS-CoV-2 infection persist for months. Science 370, 
1227-1230 (2020). doi:10.1126/science.abd7728 Medline

21. A. Sariol, S. Perlman, Lessons for COVID-19 immunity from other coronavirus infections. Immunity 53, 248-263 (2020). doi:10.1016/i.jmmuni.2020.07.005 Medline

22. K. Subbarao, SARS-CoV-2: A New Song Recalls an Old Melody. Cell Host Microbe 27, 692-694 (2020). doi:10.1016/i.chom.2020.04.019 Medline

23. W. Deng, L. Bao, J. Liu, C. Xiao, J. Liu, J. Xue, Q. Lv, F. Qi, H. Gao, P. Yu, Y. Xu, Y. Qu, F. Li, Z. Xiang, H. Yu, S. Gong, M. Liu, G. Wang, S. Wang, Z. Song, Y. Liu, W. Zhao, Y. Han, L. Zhao, X. Liu, Q. Wei, C. Qin, Primary exposure to SARS-CoV-2 protects against reinfection in rhesus macaques. Science 369, 818-823 (2020). doi:10.1126/science. abc5343 Medline

24. Q. Gao, L. Bao, H. Mao, L. Wang, K. Xu, M. Yang, Y. Li, L. Zhu, N. Wang, Z. Lv, H. Gao, X. Ge, B. Kan, Y. Hu, J. Liu, F. Cai, D. Jiang, Y. Yin, C. Qin, J. Li, X. Gong, X. Lou, W. Shi, D. Wu, H. Zhang, L. Zhu, W. Deng, Y. Li, J. Lu, C. Li, X. Wang, W. Yin, Y. Zhang, C. Qin, Development of an inactivated vaccine candidate for SARS-CoV-2. Science 369, 77-81 (2020). doi:10.1126/science.abc1932 Medline

25. A. Chandrashekar, J. Liu, A. J. Martinot, K. McMahan, N. B. Mercado, L. Peter, L. H. Tostanoski, J. Yu, Z. Maliga, M. Nekorchuk, K. Busman-Sahay, M. Terry, L. M. Wrijil, S. Ducat, D. R. Martinez, C. Atyeo, S. Fischinger, J. S. Burke, M. D. Slein, L. Pessaint, A. Van Ry, J. Greenhouse, T. Taylor, K. Blade, A. Cook, B. Finneyfrock, R. Brown, E. Teow, J. Velasco, R. Zahn, F. Wegmann, P. Abbink, E. A. Bondzie, G. Dagotto, M. S. Gebre, X. He, C. Jacob-Dolan, N. Kordana, Z. Li, M. A. Lifton, S. H. Mahrokhian, L. F. Maxfield, R. Nityanandam, J. P. Nkolola, A. G. Schmidt, A. D. Miller, R. S. Baric, G. Alter, P. K. Sorger, J. D. Estes, H. Andersen, M. G. Lewis, D. H. Barouch, SARS-CoV-2 infection protects against rechallenge in rhesus macaques. Science 369, 812-817 (2020). doi:10.1126/science. abc4776 Medline

26. S. J. Zost, P. Gilchuk, J. B. Case, E. Binshtein, R. E. Chen, J. P. Nkolola, A. Schäfer, J. X. Reidy, A. Trivette, R. S. Nargi, R. E. Sutton, N. Suryadevara, D. R. Martinez, L. E. Williamson, E. C. Chen, T. Jones, S. Day, L. Myers, A. O. Hassan, N. M. Kafai, E. S. Winkler, J. M. Fox, S. Shrihari, B. K. Mueller, J. Meiler, A. Chandrashekar, N. B. Mercado, J. J. Steinhardt, K. Ren, Y.-M. Loo, N. L. Kallewaard, B. T. McCune, S. P. Keeler, M. J. Holtzman, D. H. Barouch, L. E. Gralinski, R. S. Baric, L. B. Thackray, M. S. Diamond, R. H. Carnahan, J. E. Crowe Jr., Potently neutralizing and protective human antibodies against SARS-CoV-2. Nature 584, 443-449 (2020). doi:10.1038/s41586-020-2548-6 Medline

27. T. F. Rogers, F. Zhao, D. Huang, N. Beutler, A. Burns, W. T. He, O. Limbo, C. Smith, G. Song, J. Woehl, L. Yang, R. K. Abbott, S. Callaghan, E. Garcia, J. Hurtado, M. Parren, L. Peng, S. Ramirez, J. Ricketts, M. J. Ricciardi, S. A. Rawlings, N. C. Wu, M. Yuan, D. M. Smith, D. Nemazee, J. R. Teijaro, J. E. Voss, I. A. Wilson, R. Andrabi, B. Briney, E. Landais, D. Sok, J. G. Jardine, D. R. Burton, Isolation of potent SARSCoV-2 neutralizing antibodies and protection from disease in a small animal model. Science 369, 956-963 (2020). doi:10.1126/science.abc7520 Medline

28. A. Baum, D. Ajithdoss, R. Copin, A. Zhou, K. Lanza, N. Negron, M. Ni, Y. Wei, K. Mohammadi, B. Musser, G. S. Atwal, A. Oyejide, Y. Goez-Gazi, J. Dutton, E. Clemmons, H. M. Staples, C. Bartley, B. Klaffke, K. Alfson, M. Gazi, O. Gonzalez, E. Dick Jr., R. Carrion Jr., L. Pessaint, M. Porto, A. Cook, R. Brown, V. Ali, J. Greenhouse, T. Taylor, H. Andersen, M. G. Lewis, N. Stahl, A. J. Murphy, G. D. Yancopoulos, C. A. Kyratsous, REGN-COV2 antibodies prevent and treat SARSCoV-2 infection in rhesus macaques and hamsters. Science 370, 1110-1115 (2020). doi:10.1126/science abe2402 Medline

29. D. M. Weinreich, S. Sivapalasingam, T. Norton, S. Ali, H. Gao, R. Bhore, B. J. Musser, Y. Soo, D. Rofail, J. Im, C. Perry, C. Pan, R. Hosain, A. Mahmood, J. D. Davis, K. C. Turner, A. T. Hooper, J. D. Hamilton, A. Baum, C. A. Kyratsous, Y. Kim, A. Cook, W. Kampman, A. Kohli, Y. Sachdeva, X. Graber, B. Kowal, T. DiCioccio, N. Stahl, L. Lipsich, N. Braunstein, G. Herman, G. D. Yancopoulos; Trial Investigators, REGN-COV2, a Neutralizing Antibody Cocktail, in Outpatients with Covid-19. N. Engl. J. Med. NEJMoa2035002 (2020). doi:10.1056/NEJMoa2035002 Medline

30. Lilly announces proof of concept data for neutralizing antibody LY-CoV555 in the COVID-19 outpatient setting | Eli Lilly and Company; https://investor.lilly.com/news-releases/news-release-details/lilly-announcesproof-concept-data-neutralizing-antibody-ly.

31. D. M. Altmann, R. J. Boyton, SARS-CoV-2 T cell immunity: Specificity, function, durability, and role in protection. Sci. Immunol. 5, eabd6160 (2020). doi:10.1126/sciimmunol.abd6160 Medline

32. P. Van Damme, K. Van Herck, A review of the long-term protection after hepatitis
A and B vaccination. Travel Med. Infect. Dis. 5, 79-84 (2007). doi:10.1016/i.tmaid.2006.04.004 Medline

33. M. M. Rosado, M. Scarsella, E. Pandolfi, S. Cascioli, E. Giorda, P. Chionne, E. Madonne, F. Gesualdo, M. Romano, C. M. Ausiello, M. Rapicetta, A. R. Zanetti, A. Tozzi, R. Carsetti, Switched memory B cells maintain specific memory independently of serum antibodies: The hepatitis B example. Eur. J. Immunol. 41, 1800-1808 (2011). doi:10.1002/eji.201041187 Medline

34. F. Zhou, T. Yu, R. Du, G. Fan, Y. Liu, Z. Liu, J. Xiang, Y. Wang, B. Song, X. Gu, L. Guan, Y. Wei, H. Li, X. Wu, J. Xu, S. Tu, Y. Zhang, H. Chen, B. Cao, Clinical course and risk factors for mortality of adult inpatients with COVID-19 in Wuhan, China: A retrospective cohort study. Lancet 395, 1054-1062 (2020). doi:10.1016/S01406736(20)30566-3 Medline

35. W. A. Orenstein, R. Ahmed, Simply put: Vaccination saves lives. Proc. Natl. Acad. Sci. U.S.A. 114, 4031-4033 (2017). doi:10.1073/pnas.1704507114 Medline

36. P. Piot, H. J. Larson, K. L. O'Brien, J. N'kengasong, E. Ng, S. Sow, B. Kampmann, Immunization: Vital progress, unfinished agenda. Nature 575, 119-129 (2019). doi:10.1038/s41586-019-1656-7 Medline

37. S. Plotkin, W. Orenstein, P. Offit, Plotkin's Vaccines (Elsevier, ed. 7, 2018).

38. F. Sallusto, A. Lanzavecchia, K. Araki, R. Ahmed, From vaccines to memory and back. Immunity 33, 451-463 (2010). doi:10.1016/i.immuni.2010.10.008 Medline

39. S. Crotty, R. Ahmed, Immunological memory in humans. Semin. Immunol. 16, 197203 (2004). doi:10.1016/i.smim.2004.02.008 Medline

40. F. Weisel, M. Shlomchik, Memory B Cells of Mice and Humans. Annu. Rev. Immunol. 35, 255-284 (2017). doi:10.1146/annurev-immunol-041015-055531 Medline

41. S. M. Kissler, C. Tedijanto, E. Goldstein, Y. H. Grad, M. Lipsitch, Projecting the transmission dynamics of SARS-CoV-2 through the postpandemic period. Science 368, 860-868 (2020). doi:10.1126/science.abb5793 Medline

42. C. M. Saad-Roy, C. E. Wagner, R. E. Baker, S. E. Morris, J. Farrar, A. L. Graham, S. A. Levin, M. J. Mina, C. J. E. Metcalf, B. T. Grenfell, Immune life history, vaccination, and the dynamics of SARS-CoV-2 over the next 5 years. Science 370, 811-818 (2020). doi: 10.1126/science.abd7343 Medline

43. Q.-X. Long, X.-J. Tang, Q.-L. Shi, Q. Li, H.-J. Deng, J. Yuan, J.-L. Hu, W. Xu, Y. Zhang, F.-J. Lv, K. Su, F. Zhang, J. Gong, B. Wu, X.-M. Liu, J.-J. Li, J.-F. Qiu, J. Chen, A.-L. Huang, Clinical and immunological assessment of asymptomatic SARS-CoV-2 infections. Nat. Med. 26, 1200-1204 (2020). doi:10.1038/s41591-020-0965-6 Medline

44. D. F. Gudbjartsson, G. L. Norddahl, P. Melsted, K. Gunnarsdottir, H. Holm, E. Eythorsson, A. O. Arnthorsson, D. Helgason, K. Bjarnadottir, R. F. Ingvarsson, B. Thorsteinsdottir, S. Kristjansdottir, K. Birgisdottir, A. M. Kristinsdottir, M. I. Sigurdsson, G. A. Arnadottir, E. V. Ivarsdottir, M. Andresdottir, F. Jonsson, A. B. Agustsdottir, J. Berglund, B. Eiriksdottir, R. Fridriksdottir, E. E. Gardarsdottir, M. Gottfredsson, O. S. Gretarsdottir, S. Gudmundsdottir, K. R. Gudmundsson, T. R. Gunnarsdottir, A. Gylfason, A. Helgason, B. O. Jensson, A. Jonasdottir, H. Jonsson, T. Kristjansson, K. G. Kristinsson, D. N. Magnusdottir, O. T. Magnusson, L. B. Olafsdottir, S. Rognvaldsson, L. le Roux, G. Sigmundsdottir, A. Sigurdsson, G. Sveinbjornsson, K. E. Sveinsdottir, M. Sveinsdottir, E. A. Thorarensen, B. Thorbjornsson, M. Thordardottir, J. Saemundsdottir, S. H. Kristjansson, K. S. Josefsdottir, G. Masson, G. Georgsson, M. Kristjansson, A. Moller, R. Palsson, T. Gudnason, U. Thorsteinsdottir, I. Jonsdottir, P. Sulem, K. Stefansson, Humoral Immune Response to SARS-CoV-2 in Iceland. N. Engl. J. Med. 383, 1724-1734 (2020). doi:10.1056/NEJMoa2026116 Medline

45. A. Wainberg, F. Amanat, A. Firpo, D. R. Altman, M. J. Bailey, M. Mansour, M. McMahon, P. Meade, D. R. Mendu, K. Muellers, D. Stadlbauer, K. Stone, S. Strohmeier, V. Simon, J. Aberg, D. L. Reich, F. Krammer, C. Cordon-Cardo, Robust neutralizing antibodies to SARS-CoV-2 infection persist for months. Science 370 , 1227-1230 (2020). doi:10.1126/science.abd7728 Medline

46. L. Piccoli, Y.-J. Park, M. A. Tortorici, N. Czudnochowski, A. C. Walls, M. Beltramello, C. Silacci-Fregni, D. Pinto, L. E. Rosen, J. E. Bowen, O. J. Acton, S. Jaconi, B. Guarino, A. Minola, F. Zatta, N. Sprugasci, J. Bassi, A. Peter, A. De Marco, J. C. Nix, F. Mele, S. Jovic, B. F. Rodriguez, S. V. Gupta, F. Jin, G. Piumatti, G. Lo Presti, A. F. Pellanda, M. Biggiogero, M. Tarkowski, M. S. Pizzuto, E. Cameroni, C. HavenarDaughton, M. Smithey, D. Hong, V. Lepori, E. Albanese, A. Ceschi, E. Bernasconi, L. Elzi, P. Ferrari, C. Garzoni, A. Riva, G. Snell, F. Sallusto, K. Fink, H. W. Virgin, A. Lanzavecchia, D. Corti, D. Veesler, Mapping neutralizing and immunodominant 
sites on the SARS-CoV-2 spike receptor-binding domain by structure-guided highresolution serology. Cell 183, 1024-1042.e21 (2020). doi:10.1016/i.cell.2020.09.037 Medline

47. D. F. Robbiani, C. Gaebler, F. Muecksch, J. C. C. Lorenzi, Z. Wang, A. Cho, M. Agudelo, C. O. Barnes, A. Gazumyan, S. Finkin, T. Hägglöf, T. Y. Oliveira, C. Viant, A. Hurley, H.-H. Hoffmann, K. G. Millard, R. G. Kost, M. Cipolla, K. Gordon, F. Bianchini, S. T. Chen, V. Ramos, R. Patel, J. Dizon, I. Shimeliovich, P. Mendoza, H. Hartweger, L. Nogueira, M. Pack, J. Horowitz, F. Schmidt, Y. Weisblum, E. Michailidis, A. W. Ashbrook, E. Waltari, J. E. Pak, K. E. Huey-Tubman, N. Koranda, P. R. Hoffman, A. P. West Jr., C. M. Rice, T. Hatziioannou, P. J. Bjorkman, P. D. Bieniasz, M. Caskey, M. C. Nussenzweig, Convergent antibody responses to SARS-CoV-2 in convalescent individuals. Nature 584, 437-442 (2020). doi:10.1038/s41586-020-2456-9 Medline

48. J. Yu, L. H. Tostanoski, L. Peter, N. B. Mercado, K. McMahan, S. H. Mahrokhian, J. P. Nkolola, J. Liu, Z. Li, A. Chandrashekar, D. R. Martinez, C. Loos, C. Atyeo, S. Fischinger, J. S. Burke, M. D. Slein, Y. Chen, A. Zuiani, F. J. N. Lelis, M. Travers, S. Habibi, L. Pessaint, A. Van Ry, K. Blade, R. Brown, A. Cook, B. Finneyfrock, A. Dodson, E. Teow, J. Velasco, R. Zahn, F. Wegmann, E. A. Bondzie, G. Dagotto, M. S. Gebre, X. He, C. Jacob-Dolan, M. Kirilova, N. Kordana, Z. Lin, L. F. Maxfield, F. Nampanya, R. Nityanandam, J. D. Ventura, H. Wan, Y. Cai, B. Chen, A. G. Schmidt, D. R. Wesemann, R. S. Baric, G. Alter, H. Andersen, M. G. Lewis, D. H. Barouch, DNA vaccine protection against SARS-CoV-2 in rhesus macaques. Science 369 806-811 (2020). doi:10.1126/science.abc6284 Medline

49. B. Isho, K. T. Abe, M. Zuo, A. J. Jamal, B. Rathod, J. H. Wang, Z. Li, G. Chao, O. L. Rojas, Y. M. Bang, A. Pu, N. Christie-Holmes, C. Gervais, D. Ceccarelli, P. Samavarchi-Tehrani, F. Guvenc, P. Budylowski, A. Li, A. Paterson, F. Y. Yue, L. M. Marin, L. Caldwell, J. L. Wrana, K. Colwill, F. Sicheri, S. Mubareka, S. D. Gray-Owen, S. J. Drews, W. L. Siqueira, M. Barrios-Rodiles, M. Ostrowski, J. M. Rini, Y. Durocher, A. J. McGeer, J. L. Gommerman, A.-C. Gingras, Persistence of serum and saliva antibody responses to SARS-CoV-2 spike antigens in COVID-19 patients. Sci. Immunol. 5, eabe5511 (2020). 10.1126/sciimmunol.abe5511 Medline

50. L. B. Rodda, J. Netland, L. Shehata, K. B. Pruner, P. A. Morawski, C. D. Thouvenel, K. K. Takehara, J. Eggenberger, E. A. Hemann, H. R. Waterman, M. L. Fahning, Y. Chen, M. Hale, J. Rathe, C. Stokes, S. Wrenn, B. Fiala, L. Carter, J. A. Hamerman, N. P. King, M. Gale Jr., D. J. Campbell, D. J. Rawlings, M. Pepper, Functional SARSCoV-2-specific immune memory persists after mild COVID-19. Cell S00928674(20)31565-8 (2020). doi:10.1016/i.cell.2020.11.029 Medline

51. C. W. Davis, K. J. L. Jackson, A. K. McElroy, P. Halfmann, J. Huang, C. Chennareddy, A. E. Piper, Y. Leung, C. G. Albariño, I. Crozier, A. H. Ellebedy, J. Sidney, A. Sette, T. Yu, S. C. A. Nielsen, A. J. Goff, C. F. Spiropoulou, E. O. Saphire, G. Cavet, Y. Kawaoka, A. K. Mehta, P. J. Glass, S. D. Boyd, R. Ahmed, Longitudinal Analysis of the Human B Cell Response to Ebola Virus Infection. Cell 177, 1566-1582.e17 (2019). doi:10.1016/i.cell.2019.04.036 Medline

52. A. Z. Wec, D. HasIwanter, Y. N. Abdiche, L. Shehata, N. Pedreño-Lopez, C. L. Moyer, Z. A. Bornholdt, A. Lilov, J. H. Nett, R. K. Jangra, M. Brown, D. I. Watkins, C. Ahlm, M. N. Forsell, F. A. Rey, G. Barba-Spaeth, K. Chandran, L. M. Walker, Longitudinal dynamics of the human B cell response to the yellow fever 17D vaccine. Proc. Natl. Acad. Sci. U.S.A. 117, 6675-6685 (2020). doi:10.1073/pnas.1921388117 Medline

53. M. F. Kotturi, B. Peters, F. Buendia-Laysa Jr., J. Sidney, C. Oseroff, J. Botten, H. Grey, M. J. Buchmeier, A. Sette, The CD8+ T-cell response to lymphocytic choriomeningitis virus involves the $L$ antigen: Uncovering new tricks for an old virus. J. Virol. 81, 4928-4940 (2007). doi:10.1128/JVI.02632-06 Medline

54. J. Neidleman, X. Luo, J. Frouard, G. Xie, G. Gill, E. S. Stein, M. McGregor, T. Ma, A. F. George, A. Kosters, W. C. Greene, J. Vasquez, E. Ghosn, S. Lee, N. R. Roan, SARS-CoV-2-specific T cells exhibit phenotypic features of helper function, lack of terminal differentiation, and high proliferation potential. Cell Rep. Med. 1, 100081 (2020). doi:10.1016/j.xcrm.2020.100081 Medline

55. S. Sridhar, S. Begom, A. Bermingham, K. Hoschler, W. Adamson, W. Carman, T. Bean, W. Barclay, J. J. Deeks, A. Lalvani, Cellular immune correlates of protection against symptomatic pandemic influenza. Nat. Med. 19, 1305-1312 (2013). doi:10.1038/nm.3350 Medline

56. R. S. Akondy, M. Fitch, S. Edupuganti, S. Yang, H. T. Kissick, K. W. Li, B. A. Youngblood, H. A. Abdelsamed, D. J. McGuire, K. W. Cohen, G. Alexe, S. Nagar, M. M. McCausland, S. Gupta, P. Tata, W. N. Haining, M. J. McElrath, D. Zhang, B. Hu, W. J. Greenleaf, J. J. Goronzy, M. J. Mulligan, M. Hellerstein, R. Ahmed, Origin and differentiation of human memory CD8 T cells after vaccination. Nature 552, 362367 (2017). doi:10.1038/nature24633 Medline

57. S. Crotty, T Follicular Helper Cell Biology: A Decade of Discovery and Diseases. Immunity 50,1132-1148 (2019). doi:10.1016/j.immuni.2019.04.011 Medline

58. J. A. Juno, H.-X. Tan, W. S. Lee, A. Reynaldi, H. G. Kelly, K. Wragg, R. Esterbauer, H. E. Kent, C. J. Batten, F. L. Mordant, N. A. Gherardin, P. Pymm, M. H. Dietrich, N. E. Scott, W.-H. Tham, D. I. Godfrey, K. Subbarao, M. P. Davenport, S. J. Kent, A. K. Wheatley, Humoral and circulating follicular helper T cell responses in recovered patients with COVID-19. Nat. Med. 26, 1428-1434 (2020). doi:10.1038/s41591020-0995-0 Medline

59. A. T. Tan, M. Linster, C. W. Tan, N. L. Bert, W. N. Chia, K. Kunasegaran, Y. Zhuang, C. Y. L. Tham, A. Chia, G. J. Smith, B. Young, S. Kalimuddin, J. G. H. Low, D. Lye, L.-F. Wang, A. Bertoletti, Early induction of SARS-CoV-2 specific T cells associates with rapid viral clearance and mild disease in COVID-19 patients. bioRxiv 2020.10.15.341958 [Preprint]. 16 October 2020 https://doi.org/10.1101/2020.10.15.341958.

60. C. Gaebler, Z. Wang, J. C. C. Lorenzi, F. Muecksch, S. Finkin, M. Tokuyama, M. Ladinsky, A. Cho, M. Jankovic, D. Schaefer-Babajew, T. Y. Oliveira, M. Cipolla, C. Viant, C. O. Barnes, A. Hurley, M. Turroja, K. Gordon, K. G. Millard, V. Ramos, F. Schmidt, Y. Weisblum, D. Jha, M. Tankelevich, J. Yee, I. Shimeliovich, D. F. Robbiani, Z. Zhao, A. Gazumyan, T. Hatziioannou, P. J. Bjorkman, S. Mehandru, P. D. Bieniasz, M. Caskey, M. C. Nussenzweig, Evolution of Antibody Immunity to SARS-CoV-2. bioRxiv 2020.11.03.367391 (2020). 10.1101/2020.11.03.367391 Medline

61. S. Crotty, P. Felgner, H. Davies, J. Glidewell, L. Villarreal, R. Ahmed, Cutting edge: Long-term B cell memory in humans after smallpox vaccination. J. Immunol. 171, 4969-4973 (2003). doi:10.4049/iimmunol.171.10.4969 Medline

62. X. Yu, T. Tsibane, P. A. McGraw, F. S. House, C. J. Keefer, M. D. Hicar, T. M. Tumpey, C. Pappas, L. A. Perrone, O. Martinez, J. Stevens, I. A. Wilson, P. V. Aguilar, E. L. Altschuler, C. F. Basler, J. E. Crowe Jr., Neutralizing antibodies derived from the B cells of 1918 influenza pandemic survivors. Nature 455, 532-536 (2008). doi:10.1038/nature07231 Medline

63. J. Zuo, A. Dowell, H. Pearce, K. Verma, H. Long, J. Begum, F. Aiano, Z. AminChowdhury, B. Hallis, L. Stapley, R. Borrow, E. Linley, S. Ahmad, B. Parker, A. Horsley, G. Amirthalingam, K. Brown, M. Ramsay, S. Ladhani, P. Moss, Robust SARS-CoV-2-specific T-cell immunity is maintained at 6 months following primary infection. bioRxiv 2020.11.01.362319 [Preprint] https://doi.org/10.1101/2020.11.01.362319.

64. E. Hammarlund, M. W. Lewis, S. G. Hansen, L. I. Strelow, J. A. Nelson, G. J. Sexton, J. M. Hanifin, M. K. Slifka, Duration of antiviral immunity after smallpox vaccination. Nat. Med. 9, 1131-1137 (2003). doi:10.1038/nm917 Medline

65. N. Le Bert, A. T. Tan, K. Kunasegaran, C. Y. L. Tham, M. Hafezi, A. Chia, M. H. Y. Chng, M. Lin, N. Tan, M. Linster, W. N. Chia, M. I.-C. Chen, L.-F. Wang, E. E. Ooi, S. Kalimuddin, P. A. Tambyah, J. G.-H. Low, Y.-J. Tan, A. Bertoletti, SARS-CoV-2specific T cell immunity in cases of COVID-19 and SARS, and uninfected controls. Nature 584, 457-462 (2020). doi:10.1038/s41586-020-2550-z Medline

66. N. B. Mercado, R. Zahn, F. Wegmann, C. Loos, A. Chandrashekar, J. Yu, J. Liu, L. Peter, K. McMahan, L. H. Tostanoski, X. He, D. R. Martinez, L. Rutten, R. Bos, D. van Manen, J. Vellinga, J. Custers, J. P. Langedijk, T. Kwaks, M. J. G. Bakkers, D. Zuijdgeest, S. K. Rosendahl Huber, C. Atyeo, S. Fischinger, J. S. Burke, J. Feldman, B. M. Hauser, T. M. Caradonna, E. A. Bondzie, G. Dagotto, M. S. Gebre, E. Hoffman, C. Jacob-Dolan, M. Kirilova, Z. Li, Z. Lin, S. H. Mahrokhian, L. F. Maxfield, F. Nampanya, R. Nityanandam, J. P. Nkolola, S. Patel, J. D. Ventura, K. Verrington, H. Wan, L. Pessaint, A. Van Ry, K. Blade, A. Strasbaugh, M. Cabus, R. Brown, A. Cook, S. Zouantchangadou, E. Teow, H. Andersen, M. G. Lewis, Y. Cai, B. Chen, A. G. Schmidt, R. K. Reeves, R. S. Baric, D. A. Lauffenburger, G. Alter, P. Stoffels, M. Mammen, J. Van Hoof, H. Schuitemaker, D. H. Barouch, Single-shot Ad26 vaccine protects against SARS-CoV-2 in rhesus macaques. Nature 586, 583-588 (2020). doi:10.1038/s41586-020-2607-z Medline

67. K. S. Corbett, B. Flynn, K. E. Foulds, J. R. Francica, S. Boyoglu-Barnum, A. P. Werner, B. Flach, S. O'Connell, K. W. Bock, M. Minai, B. M. Nagata, H. Andersen, D. R. Martinez, A. T. Noe, N. Douek, M. M. Donaldson, N. N. Nji, G. S. Alvarado, D. K. Edwards, D. R. Flebbe, E. Lamb, N. A. Doria-Rose, B. C. Lin, M. K. Louder, S. O'Dell, S. D. Schmidt, E. Phung, L. A. Chang, C. Yap, J. M. Todd, L. Pessaint, A. Van Ry, S. Browne, J. Greenhouse, T. Putman-Taylor, A. Strasbaugh, T.-A. Campbell, A. 
Cook, A. Dodson, K. Steingrebe, W. Shi, Y. Zhang, O. M. Abiona, L. Wang, A. Pegu, E. S. Yang, K. Leung, T. Zhou, I.-T. Teng, A. Widge, I. Gordon, L. Novik, R. A. Gillespie, R. J. Loomis, J. I. Moliva, G. Stewart-Jones, S. Himansu, W.-P. Kong, M. C. Nason, K. M. Morabito, T. J. Ruckwardt, J. E. Ledgerwood, M. R. Gaudinski, P. D. Kwong, J. R. Mascola, A. Carfi, M. G. Lewis, R. S. Baric, A. McDermott, I. N. Moore, N. J. Sullivan, M. Roederer, R. A. Seder, B. S. Graham, Evaluation of the mRNA1273 Vaccine against SARS-CoV-2 in Nonhuman Primates. N. Engl. J. Med. 383 1544-1555 (2020). doi:10.1056/NEJMoa2024671 Medline

68. L. Corey, J. R. Mascola, A. S. Fauci, F. S. Collins, A strategic approach to COVID-19 vaccine R\&D. Science 368, 948-950 (2020). doi:10.1126/science.abc5312 Medline

69. J. Zhao, J. Zhao, A. K. Mangalam, R. Channappanavar, C. Fett, D. K. Meyerholz, S. Agnihothram, R. S. Baric, C. S. David, S. Perlman, Airway Memory CD4+ T Cells Mediate Protective Immunity against Emerging Respiratory Coronaviruses. Immunity 44, 1379-1391 (2016). doi:10.1016/i.immuni.2016.05.006 Medline

70. W. E. Purtha, T. F. Tedder, S. Johnson, D. Bhattacharya, M. S. Diamond, Memory B cells, but not long-lived plasma cells, possess antigen specificities for viral escape mutants. J. Exp. Med. 208, 2599-2606 (2011). doi:10.1084/jem.20110740 Medline

71. D. Masopust, A. G. Soerens, Tissue-Resident T Cells and Other Resident Leukocytes. Annu. Rev. Immunol. 37, 521-546 (2019). doi:10.1146/annurevimmunol-042617-053214 Medline

72. H. C. Whittle, P. Aaby, B. Samb, H. Jensen, J. Bennett, F. Simondon, Effect of subclinical infection on maintaining immunity against measles in vaccinated children in West Africa. Lancet 353, 98-102 (1999). doi:10.1016/S01406736(98)02364-2 Medline

73. S. A. Plotkin, Vaccines: Correlates of vaccine-induced immunity. Clin. Infect. Dis. 47, 401-409 (2008). doi:10.1086/589862 Medline

74. N. Burdin, L. K. Handy, S. A. Plotkin, What Is Wrong with Pertussis Vaccine Immunity? The Problem of Waning Effectiveness of Pertussis Vaccines. Cold Spring Harb. Perspect. Biol. 9, a029454 (2017). doi:10.1101/cshperspect.a029454 Medline

75. N. van Doremalen, T. Lambe, A. Spencer, S. Belij-Rammerstorfer, J. N Purushotham, J. R. Port, V. A. Avanzato, T. Bushmaker, A. Flaxman, M. Ulaszewska, F. Feldmann, E. R. Allen, H. Sharpe, J. Schulz, M. Holbrook, A. Okumura, K. Meade-White, L. Pérez-Pérez, N. J. Edwards, D. Wright, C. Bissett, C. Gilbride, B. N. Williamson, R. Rosenke, D. Long, A. Ishwarbhai, R. Kailath, L. Rose, S. Morris, C. Powers, J. Lovaglio, P. W. Hanley, D. Scott, G. Saturday, E. de Wit, S. C. Gilbert, V. J. Munster, ChAdOx1 nCoV-19 vaccine prevents SARS-CoV-2 pneumonia in rhesus macaques. Nature 586, 578-582 (2020). doi:10.1038/s41586-020-2608-y Medline

76. R. L. Tillett, J. R. Sevinsky, P. D. Hartley, H. Kerwin, N. Crawford, A. Gorzalski, C. Laverdure, S. C. Verma, C. C. Rossetto, D. Jackson, M. J. Farrell, S. Van Hooser, M. Pandori, Genomic evidence for reinfection with SARS-CoV-2: A case study. Lancet Infect. Dis. 21, 52-58 (2021). doi:10.1016/S1473-3099(20)30764-7 Medline

77. K. K.-W. To, I. F.-N. Hung, J. D. Ip, A. W.-H. Chu, W.-M. Chan, A. R. Tam, C. H.-Y. Fong, S. Yuan, H.-W. Tsoi, A. C.-K. Ng, L. L.-Y. Lee, P. Wan, E. Tso, W.-K. To, D. Tsang, K.-H. Chan, J.-D. Huang, K.-H. Kok, V. C.-C. Cheng, K.-Y. Yuen, COVID-19 re-infection by a phylogenetically distinct SARS-coronavirus-2 strain confirmed by whole genome sequencing. Clin. Infect. Dis. ciaal275 (2020). $10.1093 / \mathrm{cid} /$ ciaal275 Medline

78. D. Wyllie, R. Mulchandani, H. E. Jones, S. Taylor-Phillips, T. Brooks, A. Charlett, A. E. Ades, EDSAB-Home Investigators, A. Makin, I. Oliver, P. Moore, J. Boyes, A. Hormis, N. Todd, I. Reckless, SARS-CoV-2 responsive T cell numbers are associated with protection from COVID-19: A prospective cohort study in keyworkers. medRxiv 2020.11.02.20222778 [Preprint]. 4 November 2020. https://doi.org/10.1101/2020.11.02.20222778.

79. S. F. Lumley, D. O'Donnell, N. E. Stoesser, P. C. Matthews, A. Howarth, S. B. Hatch, B. D. Marsden, S. Cox, T. James, F. Warren, L. J. Peck, T. G. Ritter, Z. de Toledo, L. Warren, D. Axten, R. J. Cornall, E. Y. Jones, D. I. Stuart, G. Screaton, D. Ebner, S. Hoosdally, M. Chand, O. U. H. S. T. Group, D. W. Crook, A.-M. O'Donnell, C. P. Conlon, K. B. Pouwels, A. S. Walker, T. E. Peto, S. Hopkins, T. M. Walker, K. Jeffery, D. W. Eyre, Antibodies to SARS-CoV-2 are associated with protection against reinfection. medRxiv 2020.11.18.20234369 [Preprint]. 19 November 2020. https://doi.org/10.1101/2020.11.18.20234369.
80. J. H. Beigel, K. M. Tomashek, L. E. Dodd, A. K. Mehta, B. S. Zingman, A. C. Kalil, E. Hohmann, H. Y. Chu, A. Luetkemeyer, S. Kline, D. Lopez de Castilla, R. W. Finberg, K. Dierberg, V. Tapson, L. Hsieh, T. F. Patterson, R. Paredes, D. A. Sweeney, W. R. Short, G. Touloumi, D. C. Lye, N. Ohmagari, M.-D. Oh, G. M. Ruiz-Palacios, T. Benfield, G. Fätkenheuer, M. G. Kortepeter, R. L. Atmar, C. B. Creech, J. Lundgren, A. G. Babiker, S. Pett, J. D. Neaton, T. H. Burgess, T. Bonnett, M. Green, M. Makowski, A. Osinusi, S. Nayak, H. C. Lane; ACTT-1 Study Group Members, Remdesivir for the Treatment of Covid-19 - Final Report. N. Engl. J. Med. 383, 1813-1826 (2020). doi:10.1056/NEJMoa2007764 Medline

81. D. Wrapp, N. Wang, K. S. Corbett, J. A. Goldsmith, C.-L. Hsieh, O. Abiona, B. S. Graham, J. S. McLellan, Cryo-EM structure of the 2019-nCoV spike in the prefusion conformation. Science 367, 1260-1263 (2020). doi:10.1126/science.abb2507 Medline

82. F. Amanat, D. Stadlbauer, S. Strohmeier, T. H. O. Nguyen, V. Chromikova, M. McMahon, K. Jiang, G. A. Arunkumar, D. Jurczyszak, J. Polanco, M. BermudezGonzalez, G. Kleiner, T. Aydillo, L. Miorin, D. S. Fierer, L. A. Lugo, E. M. Kojic, J. Stoever, S. T. H. Liu, C. Cunningham-Rundles, P. L. Felgner, T. Moran, A. GarcíaSastre, D. Caplivski, A. C. Cheng, K. Kedzierska, O. Vapalahti, J. M. Hepojoki, V. Simon, F. Krammer, A serological assay to detect SARS-CoV-2 seroconversion in humans. Nat. Med. 26, 1033-1036 (2020). doi:10.1038/s41591-020-0913-5 Medline

83. J. Mestecky, R. G. Hamilton, C. G. M. Magnusson, R. Jefferis, J. P. Vaerman, M. Goodall, G. G. de Lange, I. Moro, P. Aucouturier, J. Radl, C. Cambiaso, C. Silvain, J. L. Preud'homme, K. Kusama, G. M. Carlone, J. Biewenga, K. Kobayashi, F. Skvaril, C. B. Reimer, Evaluation of monoclonal antibodies with specificity for human IgA, IgA subclasses and allotypes and secretory component. Results of an IUIS/WHO collaborative study. J. Immunol. Methods 193, 103-148 (1996) doi:10.1016/0022-1759(95)00289-8 Medline

84. GraphPad, GraphPad Prism 8 Curve Fitting Guide (2020); www.graphpad.com/guides/prism/8/curve-fitting/index.htm.

\section{ACKNOWLEDGMENTS}

We would like to thank the LJI Clinical Core, specifically Gina Levi, RN and Brittany Schwan for healthy donor enrollment and blood sample procurement. We thank Carolyn Moderbacher for input on data analysis. We are also grateful to the Mt. Sinai Personalized Virology Initiative for sharing banked samples from study participants with COVID-19. We are grateful to Dr. A. Wajnberg for study participant referrals and to the Personalized Virology Initiative (Dr. G. Kleiner, Dr. LCF Mulder, Dr. M. Saksena, K. Srivastava, C. Gleason, C. M. BermúdezGonzález, K. Beach, K. Russo, L. Sominsky, E. Ferreri, R. Chernet, L. Eaker, A. Salimbangon, D. Jurczyszak, H. Alshammary, W. Mendez, A. Amoako, S. Fabre, S. Suthakaran, M. Awawda, E. Hirsch, A. Shin) for sharing banked samples from study participants with COVID-19. Funding: This work was funded by the NIH NIAID under awards Al142742 (Cooperative Centers for Human Immunology) (A.S., S.C.), NIH contract Nr. 75N9301900065 (D.W., A.S.), U01 Al141995-03 (A.S., P.B.), and U01 CA260541-01 (D.W). This work was additionally supported in part by LJI Institutional Funds, the John and Mary Tu Foundation (D.S.), the NIAID under K08 award Al135078 (J.M.D.), UCSD T32s AI007036 and AI007384 Infectious Diseases Division (S.I.R., S.A.R.), and the Bill and Melinda Gates Foundation INV-006133 from the Therapeutics Accelerator, Mastercard, Wellcome, private philanthropic contributions (K.M.H., E.O.S., S.C.), and a FastGrant from Emergent Ventures in aid of COVID-19 research. This work was partially supported by the NIAID Centers of Excellence for Influenza Research and Surveillance (CEIRS) contract HHSN272201400008C (F.K., for reagent generation), the Collaborative Influenza Vaccine Innovation Centers (CIVIC) contract 75N93019C00051 and the generous support of the JPB foundation (F.K., V.S.), the Cohen Foundation (V.S., F.K.), the Open Philanthropy Project (\#2020-215611; F.K., V.S.), as well as other philanthropic donations. We would also like to thank all of the COVID-19 and healthy human subjects who made this research possible through their generous blood donations. Author contributions: Conceptualization, S.C., A.S. and D.W.; Investigation, J.M.D., J.M., Y.K., K.M.H., E.D.Y., C.E.F., A.G., S.H., C.N.; Formal Analysis, J.M.D., J.M., Y.K., K.M.H., C.E.F., S.H., B.P., D.W., A.S., S.C.; Patient Recruitment and Samples, S.I.R., A.F., S.A.R., F. K., V. S., D.M.S., D.W.; Material Resources, F.K., V.S., V.R., E.O.S., D.W., A.S., S.C.; Data Curation, Y.K., J.M.D., J.M., S.H.; Writing, Y.K., 
J.M.D., J.M., S.I.R., D.W., A.S., S.C.; Supervision, D.W., A.S., S.C., Project Administration, A.F. Competing interests: A.S. is a consultant for Gritstone, Flow Pharma, Merck, Epitogenesis, Gilead and Avalia. S.C. is a consultant for Avalia. LJI has filed for patent protection for various aspects of T cell epitope and vaccine design work. Mount Sinai has licensed serological assays to commercial entities and has filed for patent protection for serological assays. D.S., F.A., V.S. and F.K. are listed as inventors on the pending patent application (F.K., V.S.), and Newcastle disease virus (NDV)-based SARS-CoV-2 vaccines that name F.K. as inventor. All other authors declare no conflict of interest. Data and materials availability: All data are provided in the Supplementary Materials. Epitope pools utilized in this paper will be made available to the scientific community upon request and execution of a material transfer agreement (MTA). This work is licensed under a Creative Commons Attribution 4.0 International (CC BY 4.0) license, which permits unrestricted use, distribution, and reproduction in any medium, provided the original work is properly cited. To view a copy of this license, visit https://creativecommons.org/licenses/by/4.0/. This license does not apply to figures/photos/artwork or other content included in the article that is credited to a third party; obtain authorization from the rights holder before using such material.

\section{SUPPLEMENTARY MATERIALS}

science.sciencemag.org/cgi/content/full/science.abf4063/DC1

Figs. S1 to S10

Tables S1 and S2

MDAR Reproducibility Checklist

Data File S1

23 October 2020; accepted 23 December 2020

Published online 6 January 2021

10.1126/science.abf4063 

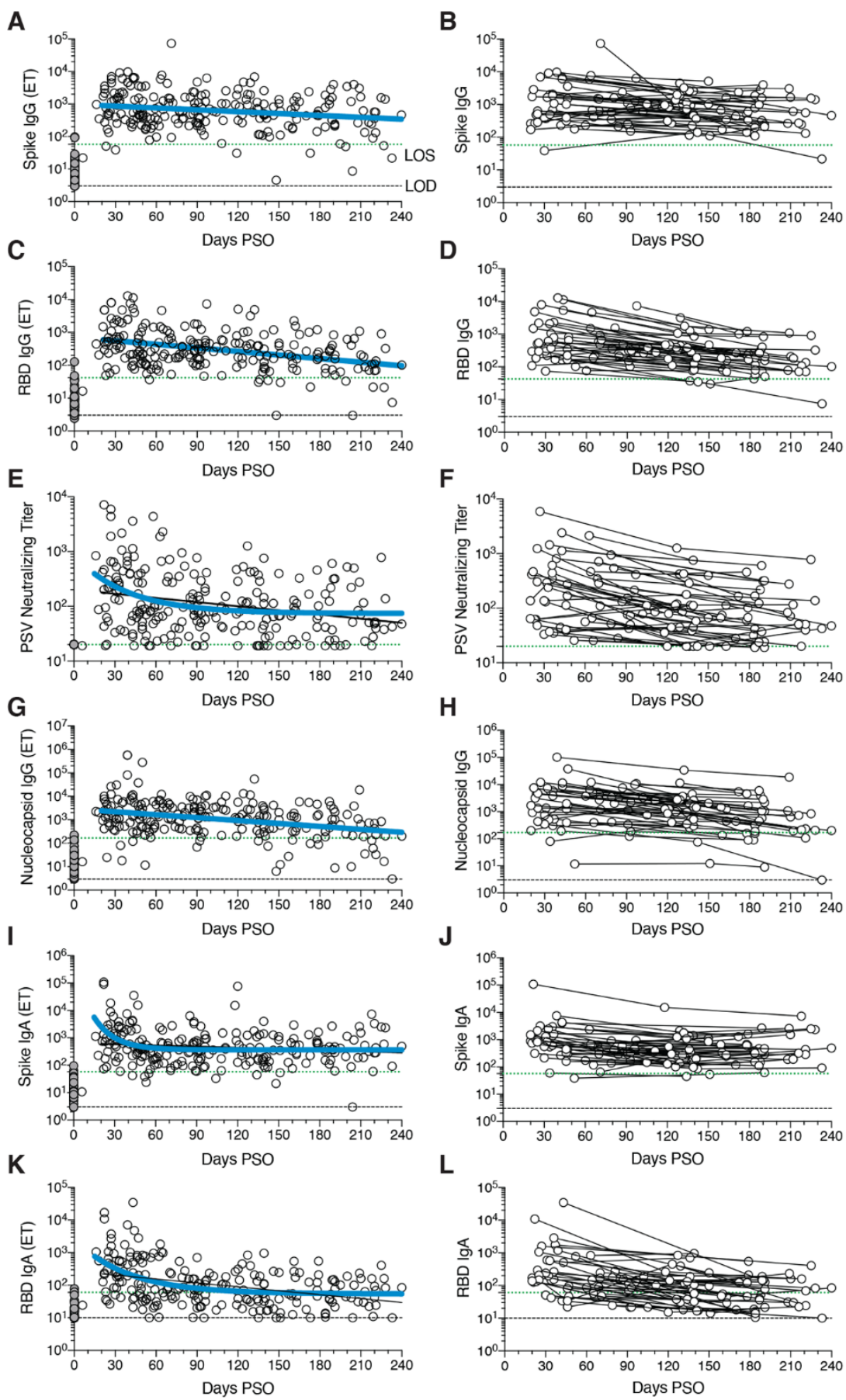

$\mathbf{L}$

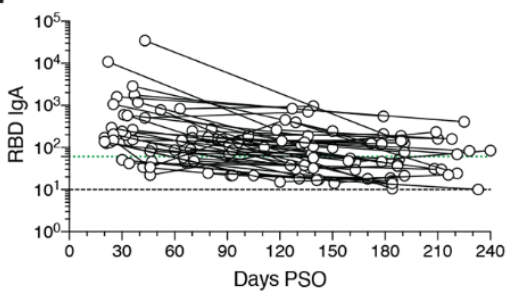


Fig. 1. Circulating antibodies to SARS-CoV-2 over time. (A) Cross-sectional Spike IgG from COVID-19 subject plasma samples $(n=228)$. Continuous decay preferred model for best fit curve, $t_{1 / 2}=140$ days, $95 \% \mathrm{Cl}: 89-325$ days. $R=-0.23, p=0.0006$. (B) Longitudinal Spike IgG ( $n=51$ ), average $t_{1 / 2}=103$ days, $95 \% \mathrm{Cl}$ : $65-235$ days (C) Cross-sectional RBD IgG. Continuous decay preferred model for best fit curve, $t_{1 / 2}=83$ days, $95 \% \mathrm{Cl}: 62$ to 126 days. $R=-0.36, p<0.0001$. (D) Longitudinal RBD IgG, average $t_{1 / 2}=69$ days, $95 \% \mathrm{Cl}$ : $58-87$ days (E) Crosssectional SARS-CoV-2 PSV neutralizing titers. One-phase decay (blue line) preferred model for best fit curve, initial $t_{1 / 2}=27$ days, $95 \% \mathrm{Cl} 11-157 \mathrm{~d}$. $R=-0.32$. Continuous decay fit line shown as black line. $(\mathrm{F})$ Longitudinal PSV neutralizing titers of SARS-CoV-2 infected subjects, average $t_{1 / 2}=90$ days, $95 \% \mathrm{Cl}$ : $70-125$ days. (G) Crosssectional Nucleocapsid IgG. Continuous decay preferred model for best fit curve, $t_{1 / 2}=68$ days, $95 \% \mathrm{Cl}: 50-106$ days. $R=-0.34, p<0.0001$. $(\mathrm{H})$ Longitudinal Nucleocapsid IgG, average $t_{1 / 2}=68$ days, $95 \% \mathrm{Cl}: 55-90$ days. (I) Cross-sectional Spike lgA titers. One-phase decay (blue line) preferred model for best fit curve, initial $t_{1 / 2}=11$ days, $95 \% \mathrm{Cl} 5-25 \mathrm{~d}$. $\mathrm{R}=-0.30$. Continuous decay fit shown as black line. $(\mathrm{J})$ Longitudinal Spike IgA, $t_{1 / 2}=210$ days, $95 \%$ Cl 126-627 days. (K) Cross-sectional RBD IgA. One-phase decay (blue line) preferred model for best fit curve, initial $t_{1 / 2}=27$ days, $95 \% \mathrm{Cl}: 15-59$ days. $R=-0.45$. Continuous decay line fit shown in black. $(\mathrm{L})$ Longitudinal RBD IgA, average $t_{1 / 2}=74$ days, 95\% Cl: 56-107 days. For cross-sectional analyses, SARS-CoV-2 infected subjects (white circles, $\mathrm{n}=238$ ) and unexposed subjects (gray circles, $\mathrm{n}=51$ ). For longitudinal samples, SARS-CoV-2 subjects $(n=51)$. The dotted black line indicates limit of detection (LOD). The dotted green line indicates limit of sensitivity (LOS) above uninfected controls. Unexposed = gray, COVID subjects $=$ white. Log data analyzed in all cases. Thick blue line represents best fit curve. When two fit curves are shown, the thin black line represents the alternative fit curve. 



B

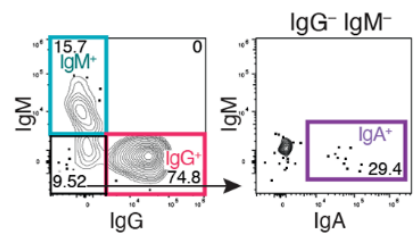

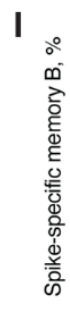

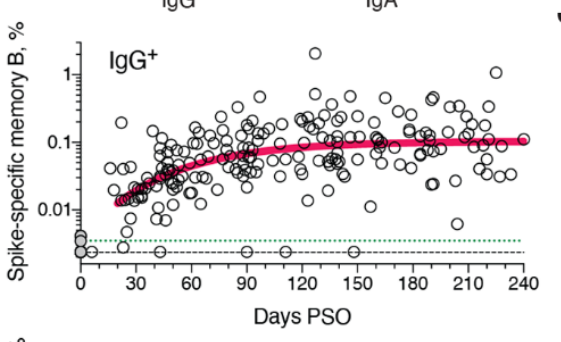

$K$ 。

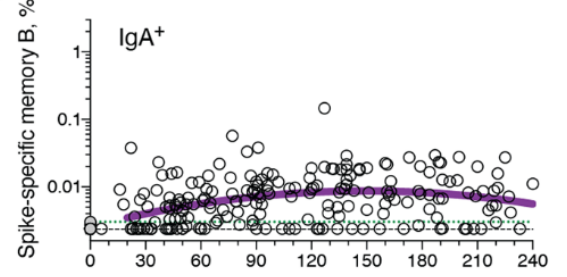

$M$

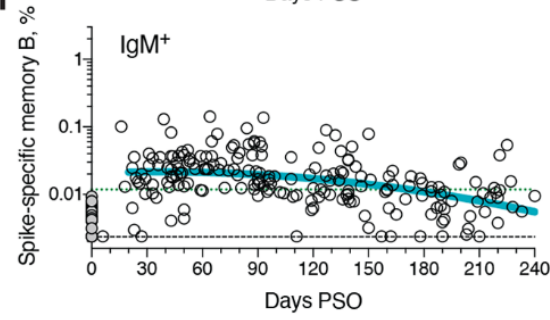

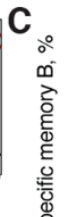

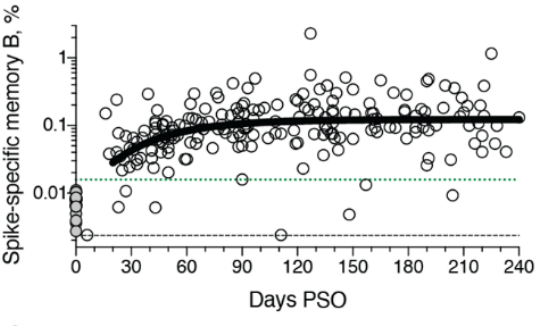

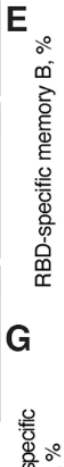
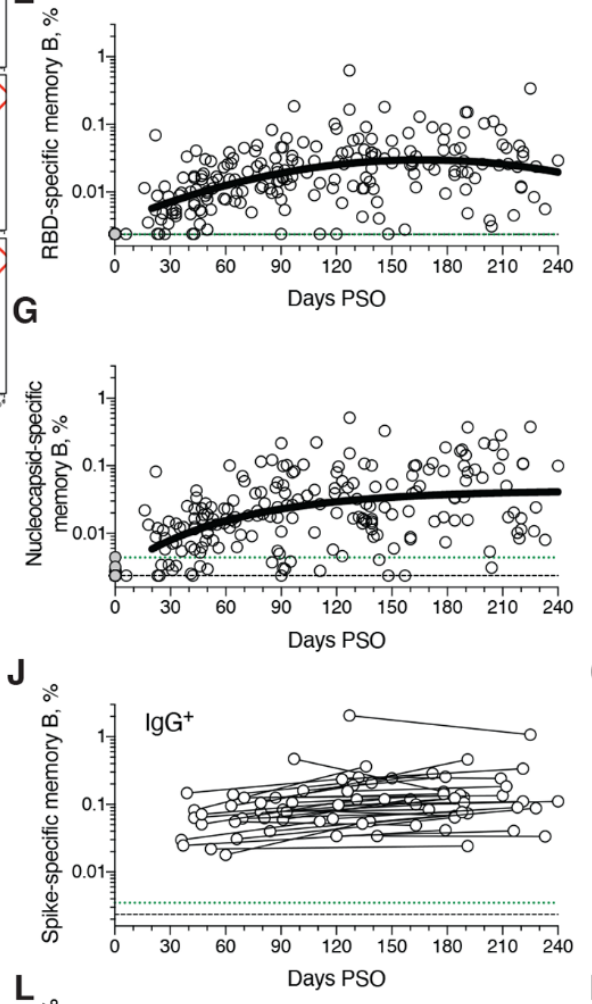

L。

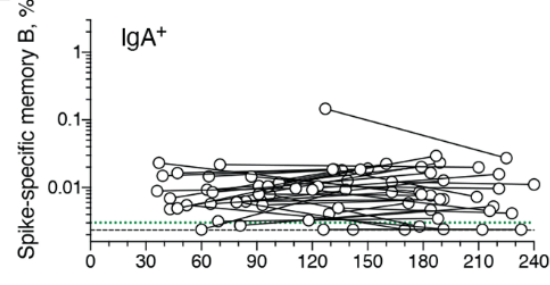

$\mathrm{N}_{\circ}$

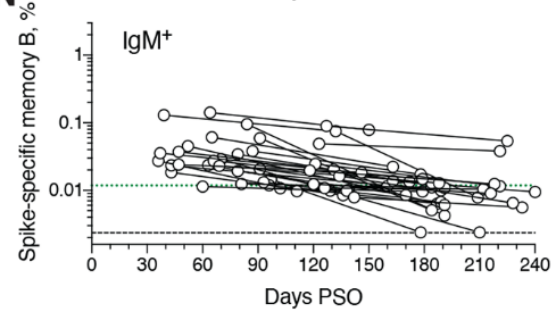

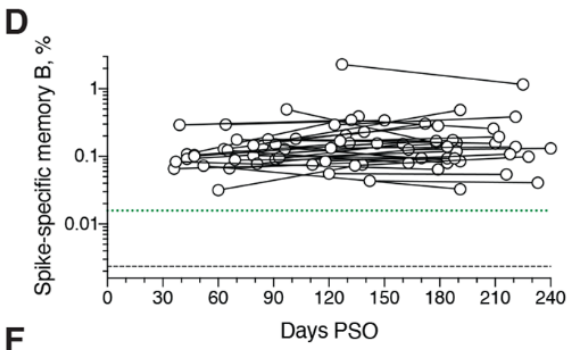

$F$ 。
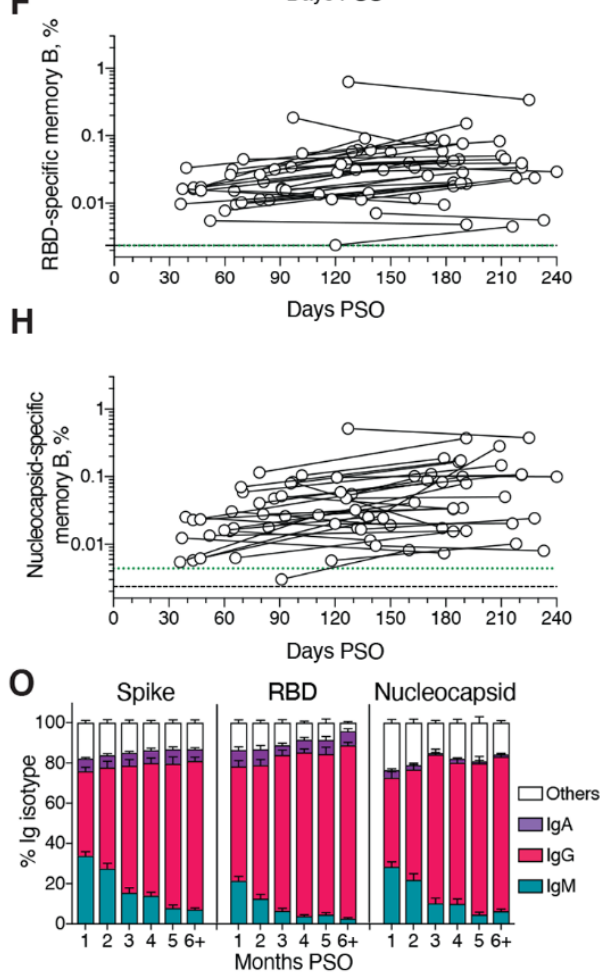

$\mathbf{P}$
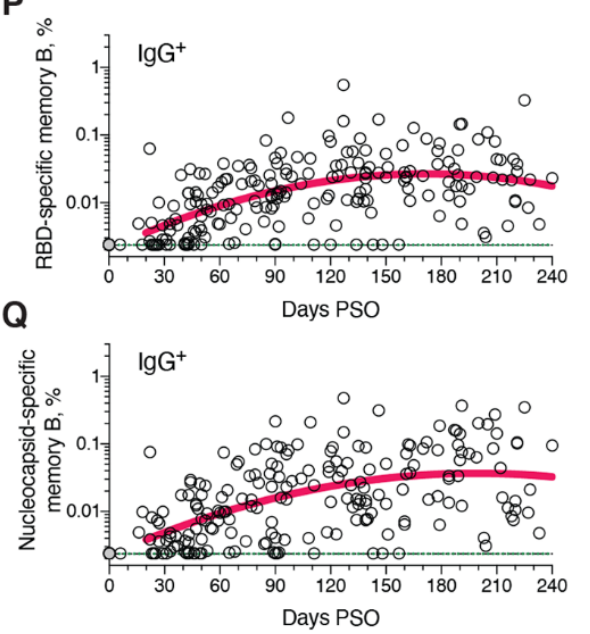
Fig. 2. Kinetics of SARS-CoV-2 memory B cell responses. (A) Example flow cytometry plots showing staining patterns of SARS-CoV-2 antigen probes on memory B cells (See fig. S1 for gating). One unexposed donor and three convalescent COVID-19 subjects are shown. Numbers indicate percentages. (B) Gating strategies to define $\operatorname{lgM}^{+}, \operatorname{lgG}$, or IgA+ SARS-CoV-2 Spike-specific memory B cells. The same gating strategies were used for RBD- or Nucleocapsid-specific B cells. (C) Cross-sectional analysis of frequency (\% of CD19+ CD20+ B cells) of SARS-CoV$2 \mathrm{~S}$-specific total $\left(\operatorname{lgG}^{+}, \operatorname{lgM}^{+}\right.$, or $\left.\operatorname{lgA}^{+}\right)$memory B cells. Pseudo-first order kinetic model for best fit curve $(R=0.38)$. (D) Longitudinal analysis of SARS-CoV-2 Spike-specific memory B cells. (E) Cross-sectional analysis of SARSCoV-2 RBD-specific total ( $\operatorname{lgG}^{+}$, $\operatorname{lgM}^{+}$, or $\left.\lg A^{+}\right)$memory B cells. Second order polynomial model for best fit curve $(R=0.46)$. ( $F)$ Longitudinal analysis of SARS-CoV-2 RBD-specific memory B cells. (G) Cross-sectional analysis of SARS-CoV-2 Nucleocapsid-specific total $\left(\operatorname{lgG}^{+}, \operatorname{lgM}^{+}\right.$, or $\left.\lg A^{+}\right)$memory B cells. Pseudo-first order kinetic model for best fit curve $(R=0.44)$. (H) Longitudinal analysis of IgG+ SARS-CoV-2 Nucleocapsid-specific memory B cells. (I) Cross-sectional analysis of SARS-CoV-2 Spike-specific lgG ${ }^{+}$memory B cells. Pseudo-first order kinetic model for best fit curve $(R=0.49)$. $(\mathrm{J})$ Longitudinal analysis of SARS-CoV-2 Spike-specific lgG ${ }^{+}$memory B cells. (K) Crosssectional analysis of SARS-CoV-2 Spike-specific lgA $A^{+}$memory B cells. Second order polynomial model for best fit curve $(|R|=0.32)$. (L) Longitudinal analysis of SARS-CoV-2 Spike-specific IgA memory B cells. (M) Crosssectional analysis of SARS-CoV-2 Spike-specific lgM+ memory B cells. Second order polynomial model for best fit curve $(|\mathrm{R}|=0.41)$. (N) Longitudinal analysis of SARS-CoV-2 Spike-specific IgM+ memory B cells. (O) Fraction of SARS-CoV-2 antigen-specific memory B cells that belong to indicated lg isotypes at 1-8 months PSO. Mean \pm SEM. (P) Cross-sectional analysis of SARS-CoV-2 RBD-specific lgG ${ }^{+}$memory B cells. Second order polynomial model for best fit curve $(|R|=0.51)$. (Q) Cross-sectional analysis of SARS-CoV-2 Nucleocapsid-specific lgG ${ }^{+}$memory $B$ cells. Second order polynomial model for best fit curve $(|\mathrm{R}|=0.51$ ). $\mathrm{n}=20$ unexposed subjects (gray circles) and $\mathrm{n}=160$ COVID-19 subjects ( $\mathrm{n}=197$ data points, white circles) for cross-sectional analysis. $\mathrm{n}=36$ COVID-19 subjects ( $n=73$ data points, white circles) for longitudinal analysis. The dotted black line indicates limit of detection (LOD). The dotted green line indicates limit of sensitivity (LOS). 
A


B


D
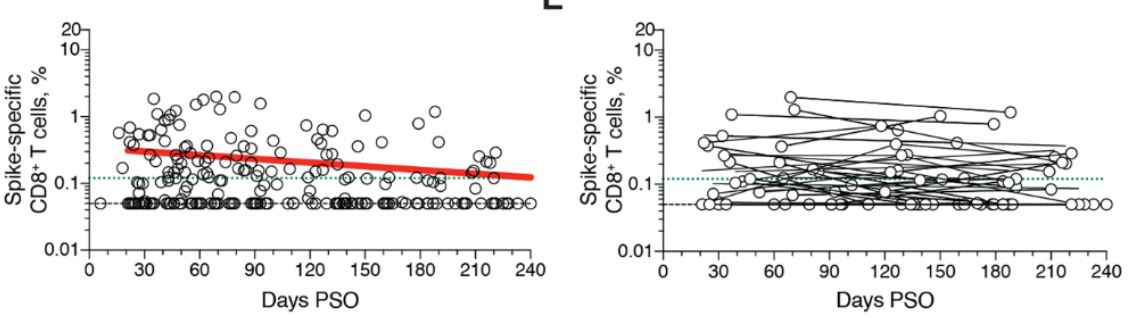

$\mathbf{F}$
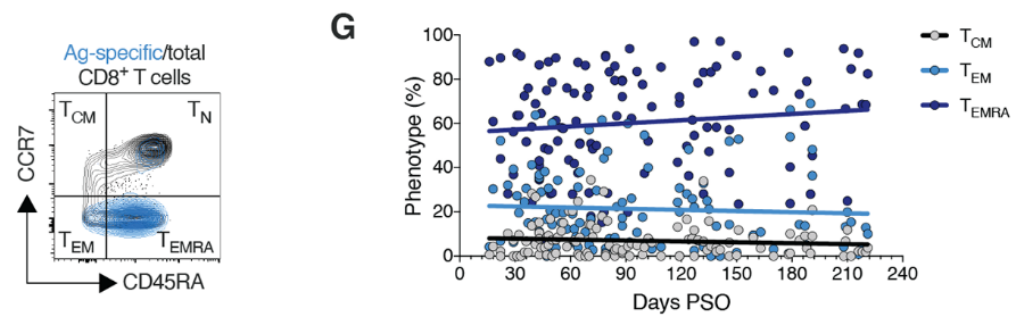

Fig. 3. SARS-CoV-2 circulating memory $\mathrm{CD}^{+} \mathrm{T}$ cells. (A) Representative flow cytometry plots of SARS-CoV-2-specific CD8 ${ }^{+} \mathrm{T}$ cells $\left(\mathrm{CD} 69^{+} \mathrm{CD} 137^{+}\right.$, See fig. S3 for gating) after overnight stimulation with S, $\mathrm{N}, \mathrm{M}$, ORF3a, or nsp3 peptide pools, compared to negative control (DMSO). (B) Cross-sectional analysis of frequency ( $\%$ of $C D 8^{+} \mathrm{T}$ cells) of total SARS-CoV-2-specific CD8 ${ }^{+} \mathrm{T}$ cells. Continuous decay preferred fit model, $t_{1 / 2}=125$ days. $R=-0.24, p=0.0003$. (C) Longitudinal analysis of total SARS-CoV-2-specific CD8 ${ }^{+} \mathrm{T}$ cells in paired samples. (D) Crosssectional analysis of Spike-specific $\mathrm{CD}^{+} \mathrm{T}$ cells. Linear decay preferred model, $t_{1 / 2}=225$ days. $R=-0.18, p=0.007$. ( $E$ ) Longitudinal analysis of Spike-specific CD8 ${ }^{+} T$ cells in paired samples. $(F, G)$ Distribution of central memory $\left(T_{C M}\right)$, effector memory $\left(T_{E M}\right)$, and terminally differentiated effector memory cells ( $T_{\text {EMRA }}$ ) among total SARS-CoV-2-specific CD8 ${ }^{+} T$ cells. $n=169$ COVID-19 subjects ( $n=215$ data points, white circles) for cross-sectional analysis. $n=37$ COVID-19 subjects $(n=83$ data points, white circles) for longitudinal analysis. The dotted black line indicates limit of detection (LOD). The dotted green line indicates limit of sensitivity (LOS). 
A
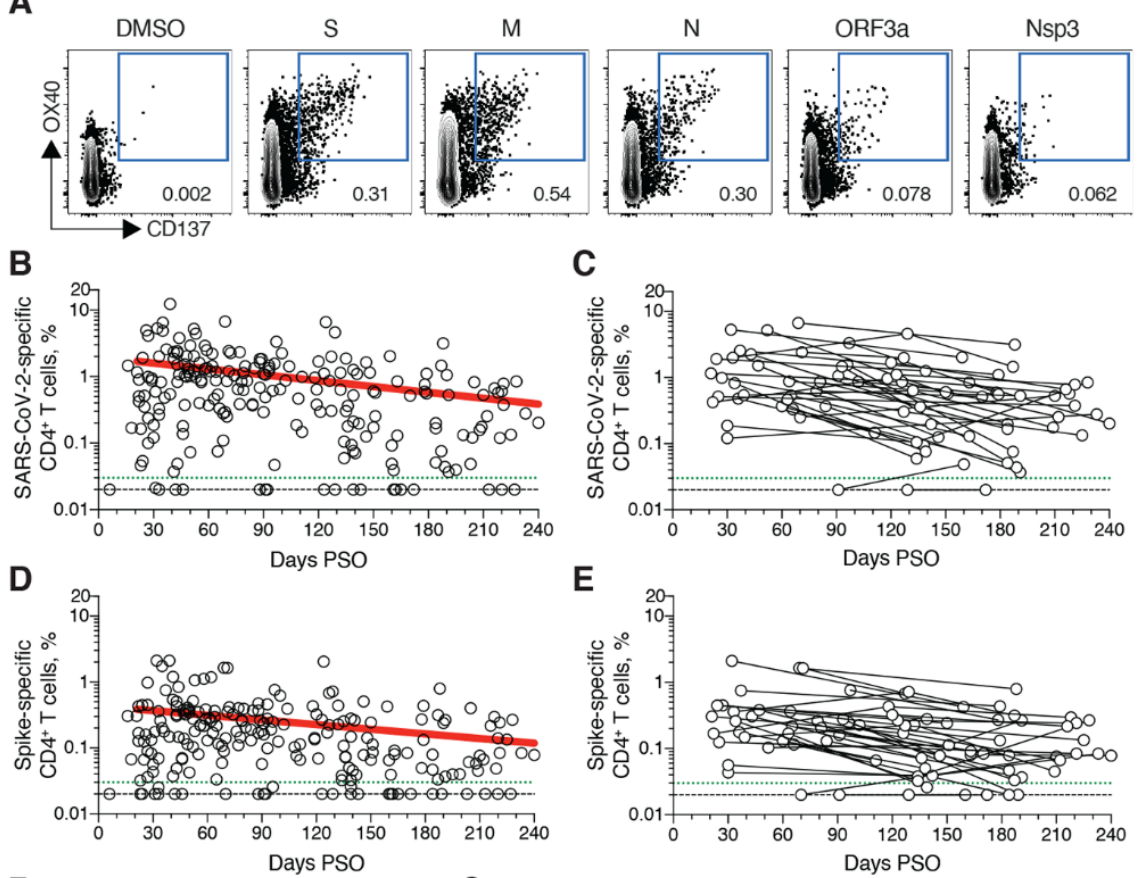

$\mathbf{F}$

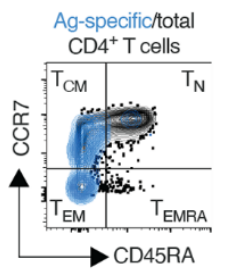

G

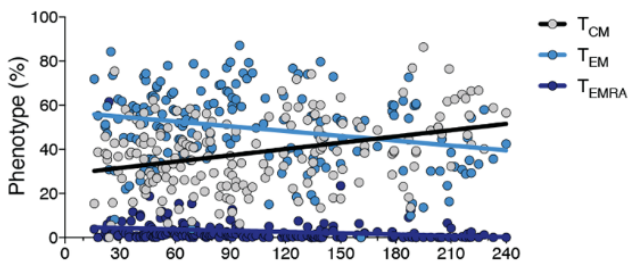
Days PSO
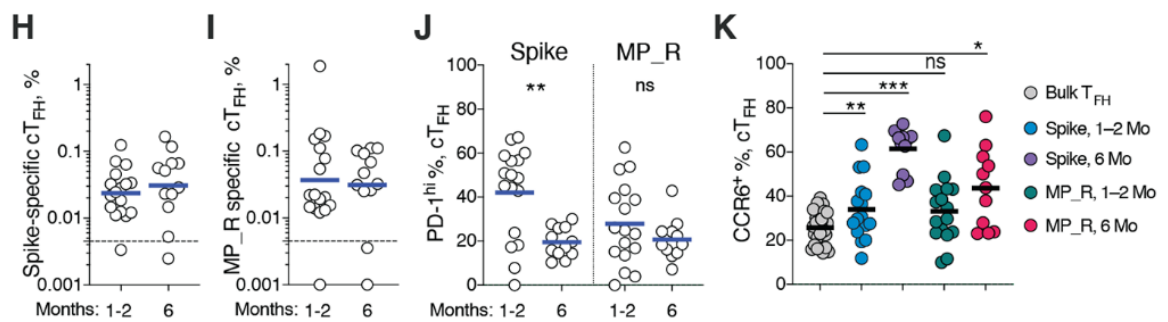

Fig. 4. SARS-CoV-2 circulating memory CD4+ $4^{+}$cells. (A) Representative flow cytometry plots of SARS-CoV-2specific $\mathrm{CD} 4^{+} \mathrm{T}$ cells $\left(\mathrm{CD} 137^{+} \mathrm{OX} 40^{+}\right.$, See fig. S4 for gating) after overnight stimulation with $\mathrm{S}, \mathrm{N}, \mathrm{M}, \mathrm{ORF} 3 \mathrm{a}$, or nsp3 peptide pools, compared to negative control (DMSO). (B) Cross-sectional analysis of frequency (\% of CD4 $4^{+} \mathrm{T}$ cells) of total SARS-CoV-2-specific CD4 ${ }^{+} T$ cells. Continuous decay preferred fit model, $t_{1 / 2}=94$ days. $R=-0.29, p<0.0001$. (C) Longitudinal analysis of total SARS-CoV-2-specific CD4+ $T$ cells in paired samples from the same subjects. (D) Crosssectional analysis of Spike-specific $C D 4^{+} T$ cells. Linear decay preferred model, $t_{1 / 2}=139$ days. $R=-0.26, p<0.0001$. $(E)$ Longitudinal analysis of Spike-specific $C D 4^{+} T$ cells in paired samples from the same subjects. $(F, G)$ Distribution of central memory $\left(T_{C M}\right)$, effector memory $\left(T_{E M}\right)$, and terminally differentiated effector memory cells ( $\left.T_{E M R A}\right)$ among total SARS-CoV-2-specific CD4 ${ }^{+} T$ cells. $(H, I)$ Quantitation of SARS-CoV-2-specific circulating $T$ follicular helper (cT $T_{F H}$ ) cells (surface $\mathrm{CD}_{40 \mathrm{O}^{+}} \mathrm{OX}_{40^{+}}$, as \% of $\mathrm{CD}^{+}{ }^{+} \mathrm{T}$ cells. See fig. S5 for gating) after overnight stimulation with (H) Spike (S) or (I) MP_R peptide pools. (J) PD-1 $1^{\text {hi }}$ SARS-CoV-2-specific $T_{F H}$ at $1-2$ months (mo) and 6 mo PSO. (K) CCR6 ${ }^{+}$SARS-CoV2-specific $\mathrm{CT}_{\mathrm{FH}}$ in comparison to bulk $\mathrm{CT} \mathrm{T}_{\mathrm{FH}}$ cells in blood. For $(\mathrm{A}-\mathrm{E}), \mathrm{n}=169$ COVID-19 subjects $(\mathrm{n}=215$ data points, white circles) for cross-sectional analysis, $n=37$ COVID-19 subjects ( $n=83$ data points, white circles) for longitudinal analysis. The dotted black line indicates limit of detection (LOD). The dotted green line indicates limit of sensitivity (LOS). For (H-J), $n=29$ COVID-19 subject samples (white circles), $n=17$ COVID-19 subjects at $1-2$ mo, $n=12$ COVID19 subjects at 6 mo. The dotted black line indicates limit of detection (LOD). Statistics by (J) Mann-Whitney U test and (K) Wilcoxon signed-rank test. ${ }^{*} p<0.05,{ }^{*} p<0.01,{ }^{* *} p<0.001$. 
A

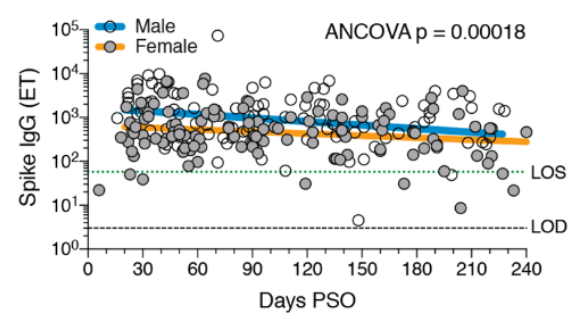

B

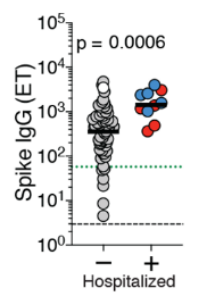

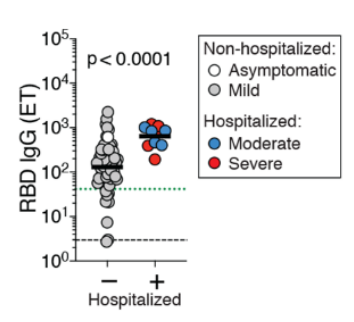

C



D

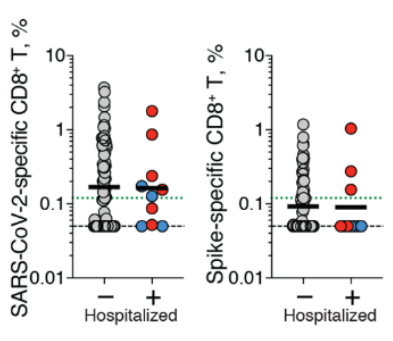

E

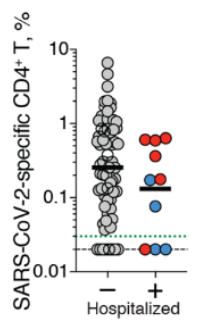

$\mathbf{F}$
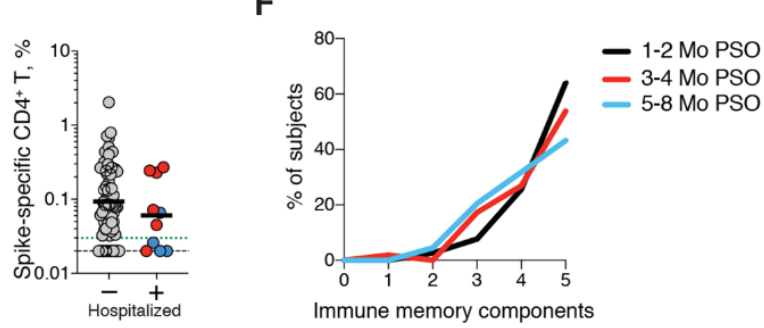

H

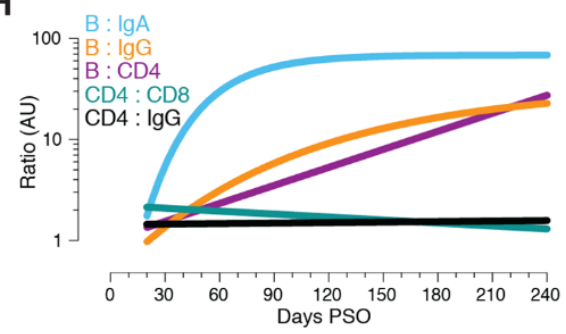

Fig. 5. Immune memory relationships. (A) Relationship between gender and Spike IgG titers over time. Males: Linear decay preferred model, $t_{1 / 2}=110$ days, $95 \% \mathrm{Cl}: 65-349$ days, $R=-0.27, p=0.0046$. Females: linear decay preferred model, $t_{1 / 2}=159$ days, $95 \% \mathrm{Cl} 88-846$ days, $\mathrm{R}=-0.22, \mathrm{p}=0.016$. ANCOVA $\mathrm{p}=0.00018$. Test for homogeneity of regressions $F=1.51, p=0.22$. (B-E) Immune memory at $120+$ days PSO in COVID-19 nonhospitalized and hospitalized subjects. Symbol colors represent peak disease severity (white: asymptomatic, gray: mild, blue: moderate, red: severe.) For subjects with multiple sample timepoints, only the final timepoint was used for these analyses. (B) Spike-specific IgG (left) and RBD-specific lgG (right) binding titers. $n=64$ (nonhospitalized), $n=10$ (hospitalized). Mann-Whitney U tests. (C) Frequency memory B cells specific to Spike (left) and RBD (right) at 120+ days PSO. $n=66$ (non-hospitalized), $n=10$ (hospitalized). Mann-Whitney $U$ tests. (D) Frequency total SARS-CoV-2-specific CD8 ${ }^{+} \mathrm{T}$ cells (left) and Spike-specific CD8 ${ }^{+} \mathrm{T}$ cells (right). $\mathrm{p}=0.72$ for total SARS-2-CoV-specific, $p=0.60$ for Spike-specific by Mann-Whitney $U$ tests. $n=72$ (non-hospitalized), $n=10$ (hospitalized). (E) Frequency total SARS-CoV-2-specific CD4+ ${ }^{+}$cells (left) and Spike-specific CD4+ ${ }^{+}$cells (right). $p=0.23$ for total SARS-CoV-2-specific, $p=0.24$ for Spike-specific by Mann-Whitney U tests $(F)$ Immune memory to SARS-CoV-2 during the early phase (1-2 mo, black line), medium phase (3-4 mo, red line), or late phase (5-8 mo, blue line). For each individual, a score of 1 was assigned for each response above LOS for RBD IgG, Spike IgA, RBD-specific memory B cells, SARS-CoV-2 specific CD4 ${ }^{+} T$ cells, and SARS-CoV-2-specific CD8 ${ }^{+}$T cells, giving a maximum total of 5 components of SARS-CoV-2 immune memory. Only COVID-19 convalescent subjects with all five immunological parameters tested were included in the analysis. $n=78(1-2 \mathrm{mo}), \mathrm{n}=52(3-4 \mathrm{mo}), \mathrm{n}=44$ (5-8 mo). (G) Percentage dot plots showing frequencies (normalized to $100 \%$ ) of subjects with indicated immune memory components as described in (B) during the early (1-2 mo) or late (5-8 mo) phase. "G", RBD-specific lgG. "B", RBD-specific memory B cells. "4", SARS-CoV-2 specific CD4+ T cells. "8", SARS-CoV-2 specific CD8 ${ }^{+} T$ cells. "A", Spike-specific IgA. $n=78(1-2 \mathrm{mo}), \mathrm{n}=44(5-8 \mathrm{mo}) .(\mathrm{H})$ Relationships between immune memory compartments in COVID-19 subjects over time, as ratios (full curves and data shown in fig. S10, B to F). AU = arbitrary units, scaled from fig. S10, B to F. "B/IgA", RBD-specific memory B cell ratio to Spike IgA antibodies. "B/lgG", RBD-specific memory B cell ratio to RBD IgG antibodies. "B/CD4", RBD-specific memory B cell ratio to SARS-CoV-2-specific CD4+ T cells. "CD4/CD8", SARS-CoV-2-specific CD4+ T cells ratio to SARS-CoV-2-specific CD8+ T cells. "CD4/IgG", SARS-CoV-2-specific CD4+ T cells ratio to RBD IgG antibodies. 
Table 1. Participant characteristics.

\begin{tabular}{|c|c|}
\hline & COVID-19 $(n=188)$ \\
\hline Age (years) & 19-81 $[$ Median $=40, \mathrm{IQR}=18.75]$ \\
\hline \multicolumn{2}{|l|}{ Gender } \\
\hline Male $(\%)$ & $43 \%(80 / 188)$ \\
\hline Female $(\%)$ & $57 \%(108 / 188)$ \\
\hline \multicolumn{2}{|l|}{ Race } \\
\hline $\begin{array}{l}\text { African American } \\
\text { or Black }(\%)\end{array}$ & $3 \%(5 / 188)$ \\
\hline & $1 \%(1 / 188)$ \\
\hline American Indian (\%) & $\begin{array}{l}\text { Asian }(\%) \\
\text { Native Hawaiian or }\end{array}$ \\
\hline \multicolumn{2}{|l|}{$\begin{array}{l}\text { Native Hawaulan or } \\
\text { Pacific Islander (\%) }\end{array}$} \\
\hline \multicolumn{2}{|l|}{ Multiracial (\%) } \\
\hline \multicolumn{2}{|l|}{ Other $(\%)$} \\
\hline \multicolumn{2}{|l|}{ Unknown (\%) } \\
\hline \multirow{2}{*}{\multicolumn{2}{|c|}{$\begin{array}{l}\text { White (\%) } \\
\text { Fthnicity }\end{array}$}} \\
\hline Ethnicity & \\
\hline Hispanic or Latino (\%) & $15 \%(28 / 188)$ \\
\hline Non-Hispanic (\%) & $80 \%(150 / 188)$ \\
\hline Unknown (\%) & $5 \%(10 / 188)$ \\
\hline \multicolumn{2}{|l|}{ Hospitalization status } \\
\hline Never hospitalized (\%) & $93 \%(174 / 188)$ \\
\hline Hospitalized (\%) & $7 \%(13 / 188)$ \\
\hline Unknown if hospitalized (\%) & $1 \%(1 / 188)$ \\
\hline Sample Collection Dates & March-October 2020 \\
\hline \multicolumn{2}{|l|}{ SARS-CoV-2 PCR Positivity } \\
\hline Positive & $77 \%(145 / 188)$ \\
\hline Negative & $1 \%(2 / 188)$ \\
\hline Not performed & $20 \%(37 / 188)$ \\
\hline Unknown & $2 \%(4 / 188)$ \\
\hline \multicolumn{2}{|l|}{ Peak Disease Severity (\%) [Female (F), Male (M)] } \\
\hline Asymptomatic (score 1) & $2 \%(4 / 188)[2 \mathrm{~F}, 2 \mathrm{M}]$ \\
\hline Mild (Non-hospitalized; Score 2-3) & $90 \%(170 / 188)[100 \mathrm{~F}, 70 \mathrm{M}]$ \\
\hline Moderate (Hospitalized; Score 4-5) & $3 \%(6 / 188)[3 \mathrm{~F}, 3 \mathrm{M}]$ \\
\hline Severe (Hospitalized; Score 6+) & $4 \%(7 / 188)[3 \mathrm{~F}, 4 \mathrm{M}]$ \\
\hline Unknown & $1 \%(1 / 188)[0 \mathrm{~F}, 1 \mathrm{M}]$ \\
\hline Days Post Symptom Onset at Collection; $n=254$ & 6-240 (Median 88, IQR 97.75) \\
\hline \multicolumn{2}{|l|}{ Blood Collection Frequency } \\
\hline $\begin{array}{l}\text { Multiple Time Point } \\
\text { Donors (2-4 times) }\end{array}$ & $27 \%(51 / 188)$ \\
\hline Single Time Point Donors & $73 \%(137 / 188)$ \\
\hline
\end{tabular}

